\title{
The Costs of Doing Hard Time: A penitentiary-based regional price index for Canada, 1883-1923
}

\author{
Chris Minns and Mary MacKinnon \\ (Trinity College, Dublin and IIIS, McGill University)
}

November, 2004

\begin{abstract}
We construct consumer price indices for Canada, mainly based on the expenditure records of Canada's federal penitentiaries. Regional price variation was much greater in Canada in the late nineteenth century than in the northern U.S. The new data suggest substantial price decline to 1900. Regional price variation in Canada decreased gradually to 1914, and quickly during the First World War. For 1900-14 and 1922-3, new data are largely consistent with consumer price data compiled by The Labour Gazette. The new data suggest more inflation during the First World War. JEL Codes: 320, 340.
\end{abstract}

Financial support for this research has come from the SSHRC. We thank Stephanie Andrews for excellent research assistance. Herb Emery kindly provided us with unpublished data and electronic versions of Labour Gazette data. We thank Alan Green for locating the Immigrant Agent reports and commenting extensively on several drafts of the paper, and Ann Carlos, Kevin O'Rourke, and Jeffrey Williamson for their comments. We thank participants at the CNEH, SCSE, and CEA conferences, the World Cliometrics Congress, seminars at TCD, University of Oxford, City University (London), and McGill for comments. 


\section{1) Introduction}

Regional economic integration is a key theme in post-Confederation Canadian economic history. When did well-integrated, "national" markets emerge? Economic historians interested in market integration have had little evidence about the distribution of prices over space and time across Canada, particularly before 1900. The 1880 s and 1890s saw the completion of the trans-continental rail line in Canada, and the beginning of largescale migration (both internal and international) to Western Canada as part of the "Wheat Boom." There is virtually no empirical evidence available to assess the impact of these developments on the dispersion in prices between regional markets within Canada.

A recent study by Emery and Levitt (2002) uses published consumer price data to trace the evolution of inter-urban consumer prices after 1900. Emery and Levitt make careful use of information in the Labour Gazette, but it has never been possible to verify the accuracy of the original reports. One main reason for improving cost of living measures is to be better able to deflate estimates of wages and earnings. Another reason for undertaking this research is to develop improved estimates of the evolution of real national income. Current estimates of real GNP before 1900 rely heavily on a Kingston (Ontario) cost of living index to deflate nominal GNP, and it is not clear to what extent Kingston prices are representative of national prices. ${ }^{1}$

This paper uses a new source to calculate inter-regional, inter-temporal price indices for Canada between 1883 and 1923. Our price data are drawn primarily from the expenditure records of federal penitentiaries, as reported to the Auditor-General of Canada by the Department of Justice. The prisons were located close to major population centres in all parts of the country. In 1880, there were federal penitentiaries in New Brunswick, Quebec, Ontario, Manitoba, and British Columbia. The Auditor General's Reports record expenditure 
by all federal government departments. The penitentiaries purchased a wider range of items than most other federal government institutions, and, conveniently for later researchers, recorded their expenses in a similar fashion every year. Most of this paper explains how we derived price indices based on these data, and evaluates the strengths and limitations of the new series.

Emery and Levitt's (2002) results suggest that there was a major split in consumer price levels between western and eastern Canada in the early 1900s, with a rapid levelling out of price variation by the end of the First World War. We find broadly similar trends in the new data. An analysis of the actual prices paid by penitentiaries shows lower prices for most goods than those reported by the Labour Gazette correspondents, but similar trends over time and by region.

The one period where our results differ substantially from those of Emery and Levitt is around the end of the First World War, with the prison prices suggesting a much sharper peak in prices than does the Labour Gazette. We discuss several possible reasons for this divergence below. One reason could be that the Department of Labour knew that the information it published had an impact on wage negotiations, and this may have influenced the gathering or reporting of consumer prices, or both. The penitentiaries had no incentive to report what they thought ought to be "normal" prices during this period of massive price fluctuations and labour unrest.

Were regional price levels converging prior to 1900 ? The new data enable us to extend our understanding of inter-regional price variation back to the years when the transcontinental railway was built and the early years of European settlement on the Prairies. We find large differences in the cost of living across Canada in the late $19^{\text {th }}$ century, with only moderate declines in regional price variability before 1900 . There appears to have been

\footnotetext{
${ }^{1}$ See Urquhart (1993). Barnett (1963) is the source of the Kingston cost of living index.
} 
considerably greater regional price variation across Canada than across the northern United States at that time.

\section{2) Other Sources of Canadian Price Data}

Previous studies of national and inter-urban price patterns in the early $20^{\text {th }}$ century have made extensive use of data collected by the federal government's Department of Labour. The Labour Gazette (abbreviation $L G$ ) published retail food, fuel and light, and rental price data for many cities for 1900 onwards, with information available monthly from 1910. The Bertram and Percy (1979) and Emery and Levitt (2002) series start in 1900 because they rely on $L G$ reports. Between 1910 and 1922, the $L G$ data were drawn from reports by Gazette correspondents in each city. The correspondents were instructed to collect price information "from retailers doing considerable trade with working men." We do not know how representative the retail prices reported by correspondents were, and whether the quality of data collection changed over time and place. The price quotations for 1900 and 1905 (for December only) were collected retrospectively from the account books of retailers later surveyed by $L G$ correspondents.

For the period before 1900, there are scattered sources of retail and wholesale prices, mainly for food and raw materials. ${ }^{2}$ Barnett's (1963) study of Kingston used a variety of sources, especially newspaper reports of prevailing market prices, as well as retailers' account books, and some prices paid by the Kingston House of Industry. ${ }^{3}$ Especially in the years around 1890, the Dominion government's immigrant agents based in cities across the country reported retail prices for a set of goods. Unlike the $L G$ reports, the immigrant agents had few instructions about the grade of each good to report on, or whether to use prices

\footnotetext{
${ }^{2}$ Paquet and Wallot (1993) constructed price indexes for Quebec City and Montreal for 1760-1867, as did Horovitz (1967) for Montreal from 1843-1867.

${ }^{3}$ Allen (1994) relies on Barnett for pre-1900 trends, and on $L G$ data for Toronto and Vancouver for 1900-1914.
} 
prevailing in a set month. Thus for a particular good, such as eggs or beef, agents sometimes report a wide range of prices.

For 1890 to 1913, wholesale prices for many items were published by the Board of Inquiry into Cost of Living in Canada (Coats report, 1915). ${ }^{4}$ Some of these series were later extended backwards by Michell (Taylor and Michell, 1931). ${ }^{5}$ Prices were generally for Toronto or Montreal, with the most extensive coverage for food products. Newspaper price reports, trade journal price reports, and some reports from producers or manufacturers, were the sources.

\section{3) Penitentiaries as a new source of price data}

The principal sources for the new index are records of expenditures for Canadian federal penitentiaries, published as part of the Annual Report of the Auditor General (abbreviation AGR) or in the Report of the Inspector of Penitentiaries (abbreviation IPR). ${ }^{6}$ In eastern Canada, penitentiaries were located in Dorchester (east of Moncton, near the New Brunswick / Nova Scotia border, to the north-east of Saint John, the largest city in New Brunswick), north of Montreal (St. Vincent de Paul), and Kingston. In Western Canada, the British Columbia Penitentiary was in New Westminster, now a suburb of Vancouver, while the Manitoba Penitentiary was in Stony Mountain, about 15 miles north of Winnipeg. ${ }^{7}$ Two new federal penitentiaries were constructed on the prairies in the early $20^{\text {th }}$ century. There was a penitentiary in Edmonton, Alberta, from 1906 to 1920. The Saskatchewan Penitentiary

\footnotetext{
${ }^{4}$ Coats (1910) provides more detail on the source of each price series.

${ }^{5}$ A few wholesale price series for Toronto date back to the $1850 \mathrm{~s}$, and there is some other wholesale price data for Montreal for the 1860s to 1880s (Hamelin and Roby, 1971). ${ }^{6}$ Criminals sentenced to a term of imprisonment of 2 years or more serve their time in a federal penitentiary. Provincial sessional papers rarely include the necessary level of detail on expenditures by other prisons.

${ }^{7}$ In 1880, the British Columbia, Manitoba, and Dorchester Penitentiaries were all new buildings. The St. Vincent de Paul penitentiary was first a reformatory for boys. In the late 1860s, Kingston Penitentiary held about 800 inmates, but Quebec inmates were transferred out by the mid-1870s.
} 
in Prince Albert opened in 1911. In some years, we also have information for the Prince Albert and Regina jails, which were run by the federal government before Saskatchewan became a province.

Table 1A shows inmate numbers. Kingston was always the largest institution. While Kingston was a fairly small, and slow-growing, city (Table 1B), Ontario was the most populous province. Most prisoners in the Kingston Penitentiary came from Ontario. One reason for using Kingston as the base for our price index is that such a large institution purchased most items every year. ${ }^{8}$ Inmate numbers by penitentiary varied considerably over time, in part because total Canadian population expanded and shifted westwards. Business cycles also mattered, with the turn-of-the-century boom and the wartime boom reducing penitentiary populations in 1902 and 1917.

The office of Auditor General was established in 1878, and the first Auditor General and his staff pursued their task vigorously (Sinclair, 1979). Correspondence with hapless civil servants who had failed to provide adequate information about expenditures was published as part of the report. It appears that penitentiary clerical staff submitted quickly and thoroughly to the firm demands of the Auditor General.

The expenses include much information relevant to the cost of living outside the prisons. Prisoners and prison officers were fed and clothed, prison buildings were heated and had lighting, and from time to time also extended and repaired. $A G R$ prices are the actual prices paid by the prisons (often with several purchases of a given item within one year), and penitentiaries across the country mainly purchased similar goods every year. ${ }^{9}$

The prices prisons paid are a mix of retail and wholesale prices, but with the manner

\footnotetext{
${ }^{8}$ Kingston also had a mental hospital and several military institutions. These purchased a similar range, and often quality, of many items.

${ }^{9}$ The later AGR list the name and location of suppliers as well as prices and quantities. In many cases, an individual supplier sold the same good to several, if not all, of the
} 
of purchase for each good likely remaining the same over the whole period. For some goods, penitentiaries' purchasing patterns were more similar to those of retail establishments than those of households. Penitentiaries were relatively large purchasers of common items (such as flour, beef, and lumber). For these items, we expect penitentiaries to have paid approximately wholesale prices, and to have mainly purchased lower grades of food and clothing. ${ }^{10}$ Building supplies, and cloth and leather purchased for guards' uniforms, were probably of at least average quality. Penitentiaries advertised for tenders for their main supplies, and complaints about the inefficiency of having each penitentiary order its own supplies appear in the Reports of the Inspector of Penitentiaries up to the 1920s (e.g. report for 1920-21, SP 35, p. 12). Some of the luxury items (such as eggs, raisins, and coffee), however, were purchased by the prisons only at Christmas, or only for the staff and hospital patients, and it is likely that prisons paid roughly retail prices for these items.

Because the prisons contracted some time in advance for most of their main supplies, we expect to see fewer sudden spikes in prices caused by temporary demand or supply shocks than would appear in the records of retailers or wholesalers. However, if a researcher surveys merchants' records at only a few points in the year, some temporary shocks will be magnified, and others missed entirely. ${ }^{11}$

Should we expect institutions to have paid unrepresentative prices for goods, and if so, would the degree of divergence have changed substantially over the years or across prisons? Political influence could have affected the awarding of contracts, but investigation of penitentiary supply patterns reveals little evidence that political affiliation was important.

penitentiaries, and it is highly likely that these were identical items.

${ }^{10}$ Every penitentiary had a farm, and various workshops as well (Curtis et al. 1985). Where a penitentiary did not purchase an important food item, such as potatoes, pork, or milk, this was usually because its farm supplied the good. We have avoided using the prison farm prices listed, instead looking for other institutions purchasing the same item.

${ }^{11}$ Coats and later Michell collected price data monthly, but Barnett mainly used June and 
There was considerable turnover in the firms supplying the penitentiaries, but turnover was not closely associated with changes in the party in power in Ottawa. If anything, political influence may have led to prisons purchasing from a broader set of suppliers than retail stores did. We often find at least two firms supplying the same common item to the larger penitentiaries in one year.

The office of the Auditor General was supposed to reduce the incidence of political patronage and other forms of corruption. A firm that failed to secure a contract knew what its competitors were receiving because Sessional Papers were public documents. The rapid turnover of suppliers may reflect low profit margins on the business, low quality of goods supplied, or ease of entering the penitentiary supply business. We expect the effects of bureaucracy to turn up in the form of wasted supplies and pilfering by guards (Royal Commissions 1914 and 1938). In addition, unauthorized expenditures may have been disguised as legitimate purchases, with bottles of whiskey listed as barrels of flour. ${ }^{12}$ None of these practices, however, would have affected the accuracy of the prices listed. The reports of the Inspector of Penitentiaries usually include the per capita costs of maintaining prisoners, and Wardens of the higher cost institutions were under pressure to reduce, or at least justify, their expenditures.

Where a penitentiary purchase price was absent, whenever possible we used prices in other federal or provincial reports, or for years of little price change, the penitentiary price from an adjacent year. ${ }^{13}$ These other institutions, like the penitentiaries, called for tenders for

December prices.

${ }^{12}$ There are reports of alcohol purchases in some years. In others, alcohol is likely included as part of prison hospitals' drug expenditures.

${ }^{13}$ For example, prior to 1891 , Kingston Penitentiary milled its own flour (we find prices only for wheat), so we use flour prices from the nearby insane asylum. Military records, records of Indian Schools, the North West Mounted Police, the Department of Public Works, and of lighthouses and steamers operated by the Department of Fisheries, all provided some missing prices. 
their main supplies. Many of the firms supplying penitentiaries were also filling other government orders. While we have some concerns about possible unstated quality differentials, in most cases where we have both a penitentiary and another government source, the prices are quite similar.

\section{4) Constructing a price index for Canada, 1883-1922}

We have selected sixteen years of the AGR around which to build our penitentiary price index: 1883/84, 1886/7, 1889/90, 1892/93, 1895/96, 1899/1900, 1905/06, 1910/11, $1913 / 14$, and all years from $1916 / 17$ to $1922 / 23$. Up to 1906 , reports are for the twelve months ending June $30^{\text {th }}$. Beginning in 1907 , the fiscal year ends March $31^{\text {st }} \cdot{ }^{14}$ The $1883 / 4$ report is the first listing detailed expenditures for food and fuel, and by 1886/7 clothing and building material prices are available. $1886 / 7$ is also the first year after the completion of the CPR main line. 1889/90, 1899/1900, 1905/06, and 1910/11 correspond with census years. The Wheat Boom is conventionally dated as having begun c. 1896, and 1913/14 was the last peacetime year. We include every year from 1916/17 on because of the rapid price increases and then decreases of the later war and post-war years. The 1922/3 AGR is the last listing prices for individual goods acquired in purchases of $\$ 500$ or less. ${ }^{15}$

A price index represents the relative cost of consumer expenditures over time or across regions. A set of weights is needed to aggregate expenditures over a range of goods. We follow most of the existing literature in constructing indices with expenditure shares fixed across time. Emery and Levitt's (2002) index uses weights adopted by Bertram and Percy (1979). For food items, weights were derived from the 1901 United States expenditure survey, while weights for fuel and light are based on 1926 Dominion Bureau of Statistics estimates of domestic national consumption. Allen's (1994) comparison of the cost of living

\footnotetext{
${ }^{14}$ Reports were published in the next series of Sessional Papers. Therefore, the 1899/1900 AGR and IPR are in 1901 Sessional Papers.
} 
in British emigrant destinations, including Canada, used weights based on British workingclass household expenditure.

Table 3 lists the five expenditure groups in our index: food, clothing, fuel and light, rent, and household operation, and Table 2 the sub-category weights. We mainly adopt the weights Haines (1989) used in his regional price index for the United States in 1890. Haines' index is based on the Aldrich Report. This report included 1889 and 1890 budget data for over 2000 families. One reason why we find Haines' weighting system attractive is that we expect a representative budget for late $19^{\text {th }}$ century American families to be similar to Canadian family budgets. These weights are fairly close to those used by Bertram and Percy (1979) and Emery and Levitt (2002), and also those chosen by Allen (1994).

We cannot check our, or any other researcher's, choice of weights for the years up to 1925, because the first national study of consumer expenditure patterns in urban Canada was conducted in 1938 (DBS, 1941). The five categories of expenditure we include in our index then covered almost 80 percent of the "typical" urban family's annual spending ${ }^{16}$ The 1938 survey showed relatively modest differences in spending on major categories across the country (and by ethnic group within Montreal and Winnipeg). Shelter costs were not highest in the biggest cities, nor did fuel and light absorb the largest proportion of budgets in the coldest places. In 1938, expenditures for shelter and household operation were somewhat higher than the weights we allow in Table 3 (37 rather than 30\%), and food expenditures correspondingly lower. By the late 1930s, urban families likely generally did live in less cramped, and better built and furnished, dwellings than families of twenty or forty years

15 The detailed IPR reports begin in 1888/89 and end with 1915/16.

${ }^{16}$ The 1938 survey also included information on expenditures for health, personal care, transportation, recreation, education, and welfare and gifts. The main criteria for inclusion in the sample were that families had to have a wage earning male head with wife and at least one child present (to a maximum of five children, except in Quebec and Montreal, where larger families were included). Family annual earnings had to be in the range $\$ 450$ - 
earlier, and as a result spent more of their earnings on these types of expenditure. As we show below, however, using the 1938 weights, rather than the assumed 1890 weights, has little impact on our results.

A second reason for adopting Haines' weights is that he provides weights for commodity subgroups as well as individual goods. Our price index for food is divided into cereal and bakery products, meat, fish and fowl, dairy, vegetables, fruit, condiments, and other foods. ${ }^{17}$ Within the food sub-categories, flour, beef, potatoes, and butter receive high weights. ${ }^{18}$ The other goods within each food sub-category receive equal weight. Keeping food commodity subgroups separate is useful as we often have price observations for several, but not all, of the goods within a sub-category in one year. When we have no price for an item, we maintain the sub-category weights derived from the Aldrich report while reweighting the contribution of the individual goods that make up the sub-category. We expect price changes of other goods in the same sub-group to be a better proxy for the missing price than the overall change in all food prices.

For the clothing sub-index, we did not use Haines' sub-category weights. In most years, the penitentiaries purchased little ready-made clothing, instead mainly buying cloth and leather. They needed supplies for prisoners' clothing, "freedom suits" for discharged inmates, officers' uniforms, bedding, and for prison workshops, which sold output to a variety of institutions. There is likely much less variation in prisons' cloth and leather purchases over time than in purchases by retail stores, as prison "fashions" changed very

2,500 .

${ }^{17}$ Haines' weights put more emphasis on the cereals component of the food index, but somewhat less on both fruits and vegetables than do the Bertram-Percy weights. Veal, cheese, bread, and apples are in the Bertram-Percy index but not in the prison price index. Barley, fish, peas, currants and raisins, salt, pepper, and molasses are included in the prison price index but not the Bertram-Percy index.

${ }^{18}$ Bread dominates Haines' cereal and bakery product index, but with few exceptions the penitentiaries baked their own bread. We substitute flour for bread in our index. 
slowly. This is another advantage of our source for the purpose of building a price index.

We include items for which we can find purchases by most penitentiaries in most years, and assign equal weight to each, except sole leather, which is double-weighted. Unfortunately, cloth prices are not reported for 1883/4. Especially in the war years, there were fewer fabric purchases, partly because there were fewer prisoners (Table 1). ${ }^{19}$ However, for virtually all prisons in all years, prices for at least one wool, one leather, and several cotton products are available.

The fuel and light sub-index consists of coal, wood (purchased by the cord), and coal oil, with the items weighted according to Haines (1989). The penitentiaries had electric light by about 1910, but we find some later prison price quotations for coal oil, as well as coal oil prices in other sections of the AGR. To supplement the prison price quotations for coal, we constructed a second series of coal prices from purchases by Dominion public buildings (mainly post offices), as the post offices generally bought more expensive grades of coal. ${ }^{20}$

The household operation category is mainly made up of items used for building and repairing dwellings, with equal weights for each item. Most would have been purchased by final consumers as well as builders. ${ }^{21} \mathrm{We}$ are not able to include prices for furniture or other

${ }^{19}$ The IPR are an excellent source of clothing prices, but the necessary level of detail is not given from 1916/17 on. The Ontario Hospital in Kingston, military records, and expenditures on Indian schools and for the relief of destitute Indians on reserves are the main supplementary sources we have used.

${ }^{20}$ The Sussex N.B. public building, the Montreal Post office, the Kingston Public building, the Winnipeg Post Office, the Regina and Prince Albert public buildings, the Edmonton post office, and the New Westminster public building were the main sources.

${ }^{21}$ For these goods, we tried to exclude specialized categories where the description (but not the price) suggested that this was not the typical item. We weight price observations by quantities bought. As expensive specialty items were generally bought in small quantities, where higher quality items were grouped under a general category, their impact on the average price is small. Sometimes penitentiaries only reported purchasing "lumber". When they gave details, almost all was spruce, pine, or (in B.C.) cedar. The oils other than cylinder oil were almost all linseed oils. We could only track the prices of black and brown Japan varnish, because most paints were bought by the pound (presumably the pigment only), with prices varying widely by colour. We include only nails purchased by 
consumer goods such as cutlery - while there are penitentiary price reports for a tremendous range of items, repeat purchases were rare. Given that most consumer durable purchases contained some iron, lumber, or oils, we hope that tracking the prices we do see repeatedly will proxy the average trends for a broader range of goods. We included both tobacco and soap as important non-durable consumption goods that did not fit elsewhere.

Information on urban rents in Canada comes from the $L G$ correspondents, and therefore is available only from 1900. Chambers (1984) calculated a rent index for Toronto, using houses advertised in the Toronto Telegram. Chambers' series suggests substantially faster rental increases over 1900-13 than does the $L G$. We cannot derive information about rents from the penitentiary or other AGR prices. We initially hoped that the prices of building materials would serve as an acceptable proxy for rent levels. However, both $L G$ and Toronto newspaper rents strongly suggest that demand shocks played a major role in setting rent levels, with rental costs shooting up when immigration levels were high. According to the $L G$, rents in western Canadian cities collapsed at the beginning of the First World War, generally only returning to 1911 to 1913 levels in 1918 or 1919 . Building costs, as we show below, were rising quickly by 1916 . Rees $(1961$, p. 101) also reports a leveling out of rents in north-eastern U.S. cities over 1914-18. Given the much larger impact of the war on the Canadian population, and the concentration of immigration in the years leading up to 1914 , the massive declines in rents reported by $L G$ correspondents may be accurate.

As we have no other source, for 1899-22 we follow Emery and Levitt (2002) in using the mean December $L G$ rents for 6 room houses with sanitary conveniences. For 1886-1895, we derived estimated rent levels, based on the relationship of rent to building costs and immigration in the 1899-1922 period. We acknowledge that these are tentative estimates. For St. John, Montreal, and Kingston, we find fragmentary references to working class rents 
in testimony to the Royal Commission on the Relations of Labour and Capital (1889), and for Kingston, also in the Ontario Bureau of Industries report. These sources suggest that in the 1880 s, few workers lived in 6 room houses with indoor conveniences. Where they did, rents were consistent with the estimates we are using.

Given the fragility of the available rent estimates, but their possible importance in affecting the resulting overall index, we calculate three price indices (Table 3). The first uses food only, because quotations for food items are found most frequently, and the quality of the items included is likely most similar across time and place. The second (CPI 1) incorporates clothing, fuel and light, household operation, and, following both US budget studies and the only Canadian source on late $19^{\text {th }}$ century expenditure patterns, allows $20 \%$ of the budget for rent (Dick, 1986, p. 480). ${ }^{22}$ The third (CPI 2) sets rent to 0, and raises the weight for the household operation category, thus implying that shelter costs are better proxied by movements in prices of building materials.

\section{5) Results}

Table 4 shows the pattern of inter-regional prices by category of expenditure. Before 1900, almost all items cost much more in western than eastern Canada, with Vancouver food prices clearly above those in Winnipeg in every year after the completion of the C.P.R. Within eastern Canada, Montreal had the highest prices. By 1910-13, the picture changed considerably. Montreal prices for everything but rent were similar to those in Kingston and New Brunswick. Price levels in Winnipeg and Vancouver were moderating, except for rents. The highest prices were often found in the booming areas of Saskatchewan and Alberta. Regional differences in food and clothing costs were clearly dropping before the

\footnotetext{
${ }^{22}$ Bertram and Percy (1979) and Emery and Levitt (2002), however, assign higher weights for rental costs in their indices.
} 
outbreak of the First World War, and this trend continued during the war. ${ }^{23}$ By the later war years, they were also much more modest for fuel and light, rent, and usually household operation. On the prairies, but not in B.C., high rents returned at war's end. The regional gaps in rents were virtually always much larger than the gaps in household operation costs. This is particularly true in the boom years of 1910, 1913, and 1920, and reinforces the point that demand conditions (and land prices) played a substantial role in determining rents paid.

Wood used for fire places and wood stoves was always supplied locally. Coal mining in western Canada (including a coal mine located on the grounds of the Alberta Penitentiary) expanded rapidly after $1910 .^{24}$ The fall in the relative cost of fuel and light in the west must be at least partly due to changes in the distance fuel had to be hauled. ${ }^{25}$ Restrictions on the import of U.S. coal were in force from 1917 to 1919: during this period most consumers in the Maritimes and the west had to purchase locally produced coal (Magrath, 1919), which was generally of lower quality as well as price. Our sources rarely allow us to work out changes in the source or type of coal burned. The prisons were likely already mainly relying on lower grades of fuel - war induced changes in quality may have been more important for the post offices. ${ }^{26}$ In several late war and postwar years, Kingston had the nation's highest fuel and light prices. We have no ready explanation for this.

We selected Kingston to be the base location to calculate changes over time both

${ }^{23}$ More items are missing from the clothing index in a given year than from the food index, and there may be more variation in the quality of the items included. This explains the sharp and temporary jumps in this sub-index for Prince Albert in 1917/18 and Vancouver in $1919 / 20$.

${ }^{24}$ The price per ton of coal produced in western Canada rose more slowly between 1914 and 1920 than did the price of coal produced in eastern Canada. Canadian Mineral Statistics 1886-1956, pp. 56, 101,104,110.

${ }^{25}$ In a few cases, prisons purchased coal from other federal institutions: if the army was selling off surplus coal before closing a military camp, the price may have been abnormally low.

${ }^{26}$ In principle, if we knew the grades of coal consumed, we could work out the relative heat efficiency of the different types of fuel. The less desirable types of coal also produced 
because the penitentiary purchased most items every year, and because when it did not, we were usually able to find prices for the same good in military or mental hospital records. As we would expect (Table 4B), late nineteenth century prices fell for the four categories we can measure, reaching a trough around 1900, and rising thereafter to a peak around 1920 . We defer to the next section comparisons of prison price trends over time with those derived from other sources.

Figures 1, 2, and 3, and Table 5, present inter-temporal, inter-regional indices for the three weighting schemes we tried. In all cases, Kingston in 1899/1900 is the base city. The differences by weighting scheme are smaller than we initially expected. The inclusion of rents in CPI 1 mainly works to raise living costs on the prairies. In the 1880 s, prices in Winnipeg and Vancouver were far higher than in the east, while Montreal prices were somewhat above Ontario or Maritime prices. By the early 1890s, Winnipeg prices had fallen close to the level of Montreal prices, although the gap between Montreal and the other eastern cities was rising at this point. Vancouver prices remained substantially higher than those found anywhere in eastern Canada, and prices in the western Prairies were closer to those of B.C. than Manitoba. As Figures 4-6 show, for the five prisons in existence in the early years, coefficients of variation, declined (at most) only modestly in the years before 1900 .

By about 1910, we see strong evidence of price convergence if rents are excluded from the index (Tables 5A and C, Figures 4 and 6). Montreal prices are now in line with those in Kingston and Dorchester. Prices in the west are still well above eastern levels, but the regional price differentials are lower, sometimes substantially lower, than in earlier years. The disruptions of the First World War clearly had an impact on regional cost-of-living differentials. By 1916, as Table 5, and Figures 4 to 6 show, consumer prices were similar across the country. For the food price index (Table 5A), the Western price premium always 
previously in evidence has been completely eliminated. While the turmoil associated with postwar inflation brought back a modest western premium, regional differentials did not return to their pre-war levels. In 1922/23, living costs in the highest price region were less than $25 \%$ above those in the lowest price region, with high rental costs on the Prairies explaining much of the gap. ${ }^{27}$

Table 5, and Figures 1 to 3, show the cost of the consumption bundle falling sharply across Canada in the late nineteenth century. In the first decade of the twentieth century, prices rose by about $30-40$ percent in the three eastern cities. The second decade of the twentieth century saw rapidly rising prices during and just after the First World War. By the time the war induced cycle of inflation and deflation was over, prices in the west (other than rents) were only modestly higher than in the east. The east/west split that had been so obvious up to about 1910 across most types of goods had largely disappeared.

Table 5 might cause one to wonder why all long-term prisoners were not shipped to eastern Canada. In fact, the regional variation in annual food cost per inmate (including the value of prison farm produce consumed in the prison) was far lower than the gap implied by Table 5A. In the early $1900 \mathrm{~s}$, it cost about $30 \%$ more to feed a prisoner in British Columbia than in Kingston, and by 1914, food costs were almost identical across the country. ${ }^{28}$

Prisoners' diets were much less varied than the diet of Table 2. Well over half the total expenditure on rations was for beef and flour. Both items were readily transportable, so smaller regional variation in provisioning prisoners is not surprising. Prisons also varied their diets according to the local cost of food, with, for example, B.C. buying more fish than Kingston. Despite the fact that the actual purchasing and producing patterns include

\footnotetext{
${ }^{27}$ We expect that this relationship continued to hold for the rest of the decade. Rents did the most to slow down the decrease in the coefficient of variation before the war (compare Figures 4, 5 and 6). In the 1920 s, the LG rents in each city were very flat.

${ }^{28}$ Details about farm products consumed within the prison are available only from 1902 to
} 
substitution away from items that were becoming more expensive, while Table $5 \mathrm{~A}$ does not allow changes in expenditure shares, we find similar increases up to 1914.

We doubt that any free citizen would have volunteered to consume a prison diet. However, with many labourers earning only $\$ 300$ - $\$ 400$ per year, the cost of prison provisions gives some clue as to how poor working class families survived. Around 1910, the un-weighted national annual average cost of the $L G$ 's food budget for a family of five was about $\$ 360$, while prisoners, almost all of whom were adult males, ate $\$ 40$ - 45 worth of food.

The evidence of Table 6 indicates that the expenditure weights we use are not imposing the patterns of Tables 4 and 5. Table 6 shows what happens to the Kingston index over time, and to the inter-regional indices at the beginning and end of the period, when we use the prison prices, but weights based on the 1938 family expenditure survey. The change in weights has little impact on either the estimated average prices over time, or regional variation in prices.

\section{6) Comparisons with other information about Canadian prices}

For most of the years covered by both our new indices and the Emery and Levitt (2002) indices, the inter-regional cost of living patterns are roughly consistent, assuming that we can match prison prices with $L G$ reports for Saint John, Montreal, Toronto, Winnipeg, Regina, Edmonton, and Vancouver. Using either set of data, inter-urban price differentials fell markedly in the second decade of the twentieth century, and prices in the early 1920 s were close to twice as high as they had been around 1900. Tables 5A and 7A show the foodonly component of penitentiary and Emery-Levitt price indices, with Kingston in 1899/1900 and Toronto in December 1900 set to $100 .^{29}$ We focus on food because the Emery-Levitt

1915.

${ }^{29}$ We have re-estimated the relative prices for each food in the Emery-Levitt series, using 
index cannot include clothing, we are using the same $L G$ rental cost information, and the low weight assigned to fuel and light mean that any differences in prices have only a slight impact on the results.

Penitentiary data generally suggest even higher western food prices than do $L G$ records. Both sources show Ontario as the low-price province in the early 1900s, not just relative to western Canada, but also relative to Quebec and the Maritimes. Manitoba prices were not dramatically above Quebec and Maritime prices in most years before the war, while from Saskatchewan to British Columbia, prices were much higher than in Ontario. By the early 1920s, regional differentials had been largely ironed out.

The one period where our indices diverge substantially from the Emery-Levitt series is around the end of the First World War, with the prison series showing substantially more inflation. ${ }^{30}$ One reason for this difference has to do with their use of December prices. For the country as a whole, $L G$ prices peaked in June, 1920, and had dropped back to late 1919 levels by December 1920, as Table 7A shows. However, our use of prices drawn from 12month periods, including some much higher price months, explains only a small part of the observed gap.

More important is the use of different weightings and grades of foods. According to the $L G$, the foods that experienced the biggest price increases during the war were typically the less-perishable, and often more readily transportable, items. By the early 1920s, the overall price increase since 1914 was usually less for more-perishable than less-perishable

1900, not 1913, as the base. For some late war and immediate post-war years, this raises the value of the index by up to 5 percentage points.

${ }^{30}$ The original $L G$ food budget for a hypothetical family of five (Table 7B, column 2 ) shows a wartime rate of inflation closer to the penitentiary price index. The $L G$ assumed that families purchased fixed quantities of each item, and used un-weighted twelve-month national averages of food prices in each city. The use of fixed quantities over time and the lack of regional weighting are questionable assumptions (Bertram and Percy, 1979, p. $301)$. 
related items. Thus the price of flour had often risen relative to the price of bread, butter relative to milk, and salt pork relative to roast pork. ${ }^{31} 44 \%$ of the Emery and Levitt food index is made up of fresh meats, milk, bread, and eggs, only $26 \%$ of our food index, assuming that none of the meat or fish purchased by the prisons was really "fresh". The prisons, and the other institutions whose records we rely on, bought flour, butter, and low quality meat in barrels.

With strong world demand for food around the end of the war, it is plausible that the price of readily exportable items would have risen relative to foods that could be sold only in the local market. By 1923, export demand had moderated substantially, but according to the $L G$, the same pattern of relative prices persisted. The spread of refrigeration, improved road transport, and increased scale of bakery production, would all have contributed to cheapening perishable relative to storable foods (Reynolds, 1938, 660).

We expect penitentiary prices were below retail prices. So long as wholesale-retail price ratios, and quality markups, did not diverge substantially over time and across the country, then prison prices will be a good proxy for consumer prices. We compared Saint John, Montreal, Kingston, Winnipeg, and Vancouver $L G$ prices for December 1900-22 to penitentiary prices for four important foodstuffs: beef, flour, butter, and potatoes (Table 8). ${ }^{32}$ We do the same for 1889/90 penitentiary prices and Immigrant Agents' 1889 price reports. It is not clear whether Immigrant Agents' answers refer to price ranges for a fixed quality by season, or quality variation in one season. In the case of butter, they were definitely reporting a lower quality than the $L G$ correspondents, and this is very likely true for beef as well. ${ }^{33}$

\footnotetext{
${ }^{31}$ Based on comparisons of June prices for 1914, 1920, and 1923.

${ }^{32}$ We thank Herb Emery for supplying us with an electronic version of the Labour Gazette data.

${ }^{33}$ The Montreal Immigrant Agent, unlike almost all his peers, continued to send in price reports until the early 1900s. For the 22 items (both food and fuel) reported in 1900, also with a price quotation by the LG Montreal correspondent for December 1900, IA prices
} 
With the exception of potatoes, the yearly average penitentiary price was almost never as much as $90 \%$ of the reported retail price, reflecting both a quality difference, and a retail markup. The ratios of potato prices bounce around considerably over time and place, probably reflecting both seasonality in potato prices and lack of transportability. We see no clear pattern of penitentiary to retail prices across cities or over time. In any one city and year, the penitentiary price of some goods may be exceptionally low, while for others it is relatively high. As Tables 5A and 7A showed, however, for most years the overall indices based on the different sources were quite similar.

We undertook the present project largely because of the scarcity of price data before 1900. There are few points of comparison for early penitentiary prices. All sources suggest that prices were high in 1883 , which happens to be the first year penitentiary data are available. We use Barnett's (1963) index to make comparisons for Kingston. Our indices suggest a quite different picture from that drawn by Barnett, (Table 7B, columns 3 and 6) with larger declines in Kingston prices for food and fuel from 1883 to 1900 . The Kingston penitentiary food price series moves more like the Toronto wholesale price index for grains and flour (column 4), and fuel and light price trends are more similar to those reported in the Department of Labour's fuel and lighting wholesale price index (column 7).

We tried to compare Kingston Penitentiary prices with Barnett's reports of changes in food prices by looking for foods with spring and fall price quotations given in the Kingston British Whig, but for 1883, 1884, 1899, and 1900, we can find only prices for flour, oatmeal, eggs, butter, mutton, and beef in both sources. ${ }^{34}$ For most of these items and years, we can find newspaper price quotations during the fiscal year that are close to the prices paid by

averaged 17 percent higher.

${ }^{34}$ In most cases, Barnett used the high price for June and December. We could not always readily locate price quotations for those months, so used late May and November where necessary. Barnett never shows price levels, only price indices. 
Kingston penitentiary. ${ }^{35}$ Undertaking a comprehensive comparison of prison and newspaper prices does not seem promising. ${ }^{36}$ Newspaper prices show considerable seasonal variation, so that collecting a range of prices over time across several cities would be extremely timeconsuming. For some items a substantial price range between low and high is given on any date, and many common food items are never, or only irregularly, listed. Over a span of years, as Barnett repeatedly mentioned in the case of Kingston, the grades of food listed in newspaper price reports change substantially. For example, in the 1880 s, pork in barrels regularly has a price listed in the British Whig, but in the late 1890 s, no prices are given for pork in barrels.

Like the penitentiary data, the Immigrant Agents' reports show a major east-west split in prices around 1890. However, within regions, this more fragmentary source suggests somewhat different price levels by city. Kingston appears as an exceptionally low priced city, relative to other cities in Ontario, as well as to cities elsewhere in eastern Canada. In 1889 and 1890, Kingston prices for a range of food items, plus soap, tobacco, and firewood, were $15-30 \%$ below Montreal and St. John prices. This evidence is well in line with what we find for Kingston and St. Vincent de Paul, though less so for Dorchester. The Immigrant Agent reports also suggest that around 1890 Winnipeg prices were closer to Vancouver prices than do penitentiary records for Manitoba and British Columbia.

Bertram and Percy used two sources of clothing prices to broaden the coverage of

${ }^{35}$ Trends in flour prices in the British Whig are almost identical to those reported by Barnett. For the other items that we were able to find in the newspaper, the majority ( 9 of 15) had relative prices that differed from those reported in Barnett by more than ten percent.

${ }^{36}$ For the 8 foods, plus firewood, where we can find regular price quotations for 1890 in the Manitoba Daily Free Press, and a Manitoba penitentiary price, the un-weighted average relative price was roughly $20 \%$ higher in the prison, but the average is heavily affected by the very high price the prison paid for potatoes. In 1899-1900, for 11 food items found in both the Montreal Star and purchased by the St. Vincent de Paul Penitentiary, prices averaged about $10 \%$ less in the prison, and a very similar result was found for the 8 food items for which we can find price quotations in the 1890 Montreal Gazette and the 
their (national) consumer price index beyond the information collected by $L G$ correspondents. For the years to 1913, they used prices from Eaton's catalogues, mainly for ready-made clothing and shoes. For later years, they relied on the D.B.S. clothing index (Bertram and Percy, 1979, p. 304). The latter has almost no ready-made clothing in it, and includes some raw or only partly processed fibres. For the years 1900-13, Eaton's prices rise much more slowly than prison prices (Table 7B, column 8). Thereafter, the indices are more similar. According to the Coats Report (1915, Vol. 1, p. 32), much of the effect of rising cloth prices was muted by a substitution of inferior materials (more cotton in mixed cottonwool fabrics, or lighter weights of fabrics). While the Coats Report presented few price series for cloth or clothing, they suggest an overall rise of 30-40 percent between 1897 and 1913. Such a change is more in line with the penitentiary records than are the Bertram-Percy findings from Eaton's Catalogues.

We have attempted to recreate our household operation sub-index by using building prices for similar goods listed in the Coats Report (1915, Vol. II) (Table 7B, column 9). The prison prices show a somewhat clearer downward trend to about 1900, and a clearer upward trend to 1913, but both sources show less of an upswing after 1900 than the food price series.

For the goods reported in both the $L G$ and the prison records, there is a high degree of similarity in most years and cities. The penitentiary data also generally match up reasonably well with other scattered Canadian price sources. The prison price levels seem to be generally in line with newspaper price reports, and below reported retail prices. For the years after 1900, except during the period of peak inflation, prison food price indices move much like those based on $L G$ prices. This gives us considerable confidence that before 1900, where comparisons with other sources can be at best fragmentary, prison prices will not mislead us about trends in consumer prices. 


\section{7) Implications of the new price series}

In the early 1890 s, price differentials across Canada were very much larger than those found at the same time in U.S. cities near the Canadian border. According to Haines (1989, p. 101), 1890 prices in Portland (Oregon) were only 10 to at most $25 \%$ higher than prices in Bangor (Maine), Syracuse (New York), Minneapolis (Minnesota) or Detroit (Michigan). ${ }^{37}$ For the present, we can only speculate on the reasons for the trans-border contrast. Despite the existence of the transcontinental rail link in Canada by 1890, western Canada was very thinly populated. Goods could readily be shipped there, but in fact volumes were low and prices correspondingly high. The tariff, again combined with the small market in the Canadian west, seems to have stopped south-north trade in most consumer goods (perhaps particularly for government institutions).

By about 1910, despite the same tariff structure, regional price variation in Canada had fallen considerably - to almost the levels of the northern U.S. twenty years before. Changes in the coefficient of variation were gradual but persistent, leading us to think that over this period there were probably many small improvements in the retail and wholesale network rather than any one major change. The merger movement of the last few pre-war years, with the expansion of nationwide firms, likely encouraged more uniform pricing policies.

What didn't converge at all in the pre-war years was rent. Rental costs in western Canada were higher than in eastern Canada in 1900, and the gap increased sharply during the settlement boom. With the outbreak of war and the almost complete end of immigration, relative housing costs across the country changed dramatically. Regional price gaps for the other categories of expenditure also fell markedly over the first few years of war, as Emery

\footnotetext{
${ }^{37}$ With Syracuse at 100, relative prices were Portland 121, Boston 113, Bangor 110, Chicago 108, Minneapolis 99, Detroit 98. Rents are excluded from this index.
} 
and Levitt (2002, p. 129) demonstrated for $L G$ data. Thus it seems that the war may have speeded up price convergence within the country by a decade or more.

The First World War was a tremendous shock to Canada. Over 650,000 men served in the Canadian Expeditionary Force (Morton, 1993, p. 278) at some time during the war, about a third of the male population of military age (15-44 in 1911). Federal government expenditure on goods and services rose from 4 to 10 percent of GNP between 1913 and 1916 (Urquhart, 1993, pp. 14, 15, 18). The boom in federal government purchases extended the geographic scope of markets for many suppliers. The price patterns we find emphasize that the war-induced alterations in the Canadian economy showed up far beyond the labour market. It is common in Canadian history to speak of the First World War as playing a large role in the creation of a sense of nationhood. Whether paying more similar prices increases a sense of community, we cannot say. But by 1916, shoppers in Winnipeg and Vancouver were paying almost the same amount for a broad range of goods as shoppers in Montreal and New Brunswick.

Canada's GNP estimates are deflated by an implicit price index (Table 7, column 1) that depends heavily on the Barnett series (for 1870-1900), the Bertram-Percy series (including clothing) for 1900-13, and a D.B.S. cost of living series that makes much use of $L G$ prices for 1913-26 (Urquhart, 1993, pp. 6-7). A full reworking of the implicit price index, using the new prison price indices instead of the patchwork of previously available series, is beyond the scope of the present paper. However, incorporating this new evidence will likely result in substantial changes in the implicit price index, and therefore in estimates of real GNP.

With a more sustained decline in prices in the late nineteenth century, growth rates during the "decades of disappointment" will rise somewhat. The Wheat Boom (1896-1913) will still appear as a major upturn in the rate of income growth, although with growth more 
concentrated in the earlier years of the boom. With more inflation during the war, the disruptive effects of the war on growth appear greater.

\section{8) Conclusions}

A compilation of actual prices paid over a forty year period across the country for a broad range of non-durable and durable items, considerably expands our knowledge of Canadian price patterns. For the years where both $L G$ and penitentiary data are available, we mainly get similar results. We therefore feel more confident about the likely reliability of both for the periods when only one is available (after 1923 and before 1900). These results are robust to moderate changes in sub-group and commodity weights.

For the years prior to 1900 , we provide the first comprehensive estimates of intertemporal, inter-regional differences in the cost of living. We find that price dispersion across the country was much higher in the early 1880 s than in 1914 . The completion of the transcontinental railway lowered prices in Winnipeg. Vancouver prices initially diverged from those in the rest of the country, and remained much higher into the early 1900s. In eastern Canada, where rail and water links were long established, Montreal prices were higher than those of southern Ontario or New Brunswick until the mid 1890s, but then dropped sharply.

As in other trading countries, Canada in the 1880s and 1890s saw declining price levels. Our data suggest that prices fell substantially more in this period than has been previously thought. After 1900, prices rose in all parts of the country, but at quite unequal rates by region. By 1913, living costs, excluding rents, were fairly well standardized. The First World War accelerated the process of price convergence, and by the early 1920s, price levels were similar across the country. While our data suggest a continuing declining variation in inter-regional living costs, the decisive break in cross-city price variation occurred during the First World War. 
We find more inflation during the First World War than do studies that rely on Labour Gazette data. This likely reflects the fact that wartime inflation was highly variable by commodity. In particular, the prices of low quality food items, of which prisons were major purchasers, appear to have been rising faster than those of higher quality food items, as recorded by the Labour Gazette. Our findings for this volatile period highlight both regional variations in inflation, and contrasts in price trends across items. When relative prices are changing rapidly, perceptions of inflation by different groups of workers, or by workers and employers, may genuinely be very different, depending on their consumption bundles. In the context of Canadian industrial relations 1917-22, this is a topic worthy of further investigation.

Around 1890, regional price differences in Canada were substantially greater than in northern regions of the U.S. Why did inter-regional cost of living differences persist later in Canada than in the United States? The substantial tariffs associated with the National Policy meant that most goods could not pass freely across the Canada-US border, and this would help allow persistently greater regional price differentials within Canada. Less developed retail and wholesale networks in Canada could also have contributed to regional price variation north of the $49^{\text {th }}$ parallel.

The primary contribution of this paper has been to construct and describe interregional cost of living differences in Canada over time. The penitentiary price data can be used to explore the microeconomics of market integration in North America in the late $19^{\text {th }}$ century. Our results will also be of use to scholars interested in income trends in Canada, especially in the years prior to 1900. A comprehensive examination of these issues awaits future research.

\section{References}

Allen, Robert C. (1994), "Real incomes in the English speaking world, 1879-1913," in 
Labour Market Evolution: the economic history of market integration, wage flexibility and the employment relation, eds. G. Grantham and M. MacKinnon. London: Routledge.

Allen, Robert C. (2001), "The great divergence in European wages and prices from the Middle Ages to the First World War." Explorations in Economic History, 38 (4), 411-447.

Barnett, Robert Francis John (1963), "A Study of Price Movements and the Cost of Living in Kingston, Ontario for the Years 1865 to 1900.” Unpublished M.A. thesis, Queen's

University.

Bertram, Gordon, and Michael B. Percy (1979), "Real wage trends in Canada 1900-1926: some provisional estimates." Canadian Journal of Economics, 12 (2), 299-312.

Canada, Board of Inquiry into Cost of Living (1915), Report. Vols. 1 and 2. Ottawa, King's Printer (Coats Report).

Canada, Department of Agriculture. Report of the Minister of Agriculture. Ottawa: King's Printer.

Canada, Department of Labour. Labour Gazette. Ottawa: King’s Printer.

Canada, Dominion Bureau of Statistics (1957), Canadian Mineral Statistics 1886-1956.

Ottawa: Queen's Printer.

Canada, Royal Commission on the Relations of Capital and Labour (1889). Report. Vols. 2, 3, 5 and 6. Ottawa: King's Printer.

Canada, Royal Commission on Penitentiaries (1914). Report. Ottawa: King’s Printer.

Canada, Royal Commission to Investigate the Penal System of Canada (1938). Report. Ottawa: King's Printer.

Chambers, Edward J. (1984), "A New Measure of the Rental Cost of Housing in the Toronto Market, 1890-1914." Histoire sociale - Social History, 17, May, 165-74.

Coats, R.H. (1910), Wholesale Prices in Canada 1890-1909. Ottawa, Department of Labour.

Curtis, Dennis, Graham, Andrew, Kelly, Lou, and Anthony Patterson (1985), Kingston Penitentiary: The First Hundred and Fifty Years, 1835-1985. Ottawa: The Correctional Service of Canada.

Dick, Trevor J.O. (1986), "Consumer Behavior in the Nineteenth Century and Ontario Workers, 1885-1889." Journal of Economic History, 46 (2), 477-488.

Dominion Bureau of Statistics (1941), Family Income and Expenditure in Canada 19371938: A Study of Urban Wage-Earner Families, including Data on Physical Attributes. Ottawa: King's Printer.

Emery, J.C. Herbert, and Clint Levitt (2002), "Cost of living, real wages, and real incomes in 
thirteen Canadian cities, 1900-1950." Canadian Journal of Economics, 35(1), 115-137.

Haines, Michael R. (1989), "A state and local consumer price index for the United States in 1890." Historical Methods, 22(3), 97-105.

Hamelin, Jean, and Yves Roby (1971), Histoire Économique du Québec 1851-1896.

Montreal: Fides.

Horovitz, William Bela (1967). "An Index of Retail Market Prices at Montreal, 1843-1867.” Unpublished M.A. thesis, McGill University.

Kingston British Whig.

Manitoba Daily Free Press. Winnipeg.

Magrath, C.A. (1919), The Final Report of the Fuel Controller, Canada. Ottawa: King's Printer.

Montreal Gazette.

Montreal Star.

Morton, Desmond (1993), When Your Number's Up: The Canadian Soldier in the First World War. Toronto: Random House.

Ontario, Bureau of Industries for the Province of Ontario (1889). Annual Report for 1888, Part IV., Wages and Cost of Living. Sessional Paper 74. Toronto.

Paquet, Gilles, and Jean-Pierre Wallot (1993), "Some Price Indexes for Quebec and Montreal (1760-1913).” Histoire Sociale/Social History, 31 (Nov.), 281-320.

Rees, Albert (1961). Real Wages in Manufacturing, 1890-1914. Princeton, Princeton UP for NBER.

Reynolds, Lloyd G. (1938), "The Canadian Baking Industry: A Study of an Imperfect Market," The Quarterly Journal of Economics, 52 (Aug.), 659-678.

Scott, Jack David (1984), Four Walls in the West: The Story of the British Columbia Penitentiary. New Westminster: Retired Federal Prison Officers' Association of British Columbia.

Sinclair, Sonja (1979), Cordial But Not Cosy: A History of the Office of the Auditor General. Toronto: McClelland and Stewart.

Taylor, K.W. and H. Michell (1931), Statistical Contributions to Canadian Economic History, vol. II. Toronto: MacMillan.

Urquhart, M.C. (1993), Gross National Product, Canada, 1870-1926: The Derivation of the Estimates. Montreal and Kingston: McGill-Queen's University Press. 
Table 1: Canadian Penitentiaries and Urban Populations, 1881-1923

A) Inmate Numbers

\begin{tabular}{|c|c|c|c|c|c|c|c|c|c|}
\hline Year & Kingston & $\begin{array}{r}\text { St. } \\
\text { Vincent } \\
\text { de Paul }\end{array}$ & $\begin{array}{r}\text { Dorchester, } \\
\text { N.B. }\end{array}$ & Manitoba & B.C. & Alberta & $\begin{array}{l}\text { Prince } \\
\text { Albert }\end{array}$ & $\begin{array}{r}\text { Regina } \\
\text { Jail }\end{array}$ & Total \\
\hline 1883 & 534 & 308 & 125 & 96 & 74 & & & & 1,137 \\
\hline 1886 & 578 & 278 & 149 & 90 & 105 & & & & 1,200 \\
\hline 1889 & 554 & 322 & 161 & 66 & 91 & & & & 1,194 \\
\hline 1892 & 532 & 374 & 172 & 75 & 75 & & & 17 & 1,245 \\
\hline 1896 & 605 & 383 & 192 & 80 & 101 & & & 29 & 1,390 \\
\hline 1899 & 570 & 447 & 226 & 112 & 90 & & 5 & 21 & 1,466 \\
\hline 1902 & 460 & 345 & 210 & 105 & 94 & & 9 & 22 & 1,236 \\
\hline 1905 & 448 & 357 & 233 & 190 & 139 & & 21 & 31 & 1,398 \\
\hline 1909 & 570 & 510 & 246 & 144 & 204 & 91 & & & 1,765 \\
\hline 1913 & 516 & 405 & 195 & 200 & 351 & 206 & 95 & & 1,958 \\
\hline 1917 & 475 & 428 & 211 & 92 & 229 & 160 & 99 & & 1,694 \\
\hline 1920 & 615 & 520 & 306 & 156 & 197 & 34 & 186 & & 1,931 \\
\hline 1923 & 729 & 625 & 363 & 218 & 216 & & 335 & & 2,486 \\
\hline
\end{tabular}

Source: Department of Justice, Report on Penitentiaries. Counts for one day - end of June to 1905, end of March thereafter. Prince Albert and Regina Jails became the responsibility of the province of Saskatchewan after 1905. Prince Albert figures for 1913 on are from Saskatchewan

Penitentiary. Alberta Penitentiary closed in 1920.

\section{B) Urban Population (,000)}

\begin{tabular}{|c|c|c|c|c|c|c|c|c|c|c|}
\hline City & Kingston & Montreal & Moncton & $\begin{array}{l}\text { Saint } \\
\text { John }\end{array}$ & Winnipeg & Vancouver & $\begin{array}{r}\text { New } \\
\text { Westminster }\end{array}$ & Edmonton & $\begin{array}{l}\text { Prince } \\
\text { Albert }\end{array}$ & Regina \\
\hline $\begin{array}{l}\text { Province } \\
1881\end{array}$ & Ontario & Quebec & N.B. & N.B. & Manitoba & B. C. & B. C. & Alberta & Sask. & Sask. \\
\hline $\begin{array}{l}1881 \\
1891\end{array}$ & 14 & 155 & 5 & 41 & 8 & & 2 & & & \\
\hline 1891 & 19 & 220 & 9 & 39 & 26 & 14 & 7 & & & \\
\hline 1901 & 18 & 328 & 9 & 41 & 42 & 27 & 6 & 4 & 2 & 2 \\
\hline 1911 & 19 & 491 & 11 & 43 & 136 & 100 & 13 & 31 & 6 & 30 \\
\hline 1921 & 22 & 649 & 17 & 47 & 179 & 117 & 14 & 59 & 8 & 34 \\
\hline
\end{tabular}

Source: 1921 Census of Canada, Vol. 1, Table 12. Population totals appear to be for city boundaries as of 1921. Populations below 1,000 not shown in the source table. 
Table 2: Sub-category weights (sum to 100)

\begin{tabular}{|c|c|c|c|c|c|c|c|c|c|}
\hline Food & & & Clothes & & Fuel and $l i$ & & $\begin{array}{c}\text { Household } \\
\text { operation }\end{array}$ & & \\
\hline Cereals and Bakery & 16 & & Braces & 6.6 & Coal & 42 & Soap & 11 & \\
\hline Flour & & 10.7 & Canvas & 6.6 & Fuel Wood & 42 & Tobacco & 11 & \\
\hline Barley & & 1.7 & Cotton & 6.6 & Coal Oil & 16 & Cement & 11 & \\
\hline Oatmeal & & 1.7 & Denim & 6.6 & & & Iron & 11 & \\
\hline Rice & & 1.7 & Hats, Straw & 6.6 & & & $\begin{array}{l}\text { Galvanized } \\
\text { iron }\end{array}$ & & 5.5 \\
\hline$\underline{\text { Meat, Fish, Poultry }}$ & 33 & & Leather, Sole & 13.3 & & & Other iron & & 5.5 \\
\hline Beef & & 18.8 & Linen & 6.6 & & & Lumber & 11 & \\
\hline Fish & & 4.7 & Lining & 6.6 & & & Nails & 11 & \\
\hline Mutton & & 4.7 & Serge & 6.6 & & & Oils & 11 & \\
\hline Bacon or Pork & & 4.7 & Shirting & 6.6 & & & Cylinder Oil & & 5.5 \\
\hline$\underline{\text { Dairy }}$ & 18 & & Silesia & 6.6 & & & Other Oil & & 5.5 \\
\hline Butter & & 11.5 & Ticking & 6.6 & & & $\begin{array}{l}\text { Japan } \\
\text { Varnish }\end{array}$ & 11 & \\
\hline Milk & & 6.5 & Tweed & 6.6 & & & Turpentine & 11 & \\
\hline$\underline{\text { Vegetables }}$ & 9 & & Yarn & 6.6 & & & & & \\
\hline Beans & & 1.8 & & & & & & & \\
\hline Potatoes & & 5.4 & & & & & & & \\
\hline Peas & & 1.8 & & & & & & & \\
\hline$\underline{\text { Fruit }}$ & 4 & & & & & & & & \\
\hline Currants and raisins & & 2 & & & & & & & \\
\hline Prunes & & 2 & & & & & & & \\
\hline$\underline{\text { Condiments }}$ & 1 & & & & & & & & \\
\hline Pepper & & 0.3 & & & & & & & \\
\hline Salt & & 0.3 & & & & & & & \\
\hline Vinegar & & 0.3 & & & & & & & \\
\hline$\underline{\text { Other foods }}$ & 20 & & & & & & & & \\
\hline Coffee & & 3.3 & & & & & & & \\
\hline Eggs & & 3.3 & & & & & & & \\
\hline Lard & & 3.3 & & & & & & & \\
\hline Molasses & & 3.3 & & & & & & & \\
\hline Sugar & & 3.3 & & & & & & & \\
\hline Tea & & 3.3 & & & & & & & \\
\hline
\end{tabular}

Table 3: Category weights for alternative price indices

Sub-category Food index Consumer price Consumer Price

Food

Clothing index 1 Index 2

Fuel and light 100 46

$0 \quad 17$

Household

0

7

10

46

operation

Rent 
Table 4: Price Indices by Expenditure Category

A) Inter-regional Price Indices by expenditure category (Kingston =100)

\begin{tabular}{|c|c|c|c|c|c|c|}
\hline & Dorchester & Montreal & Winnipeg & $\begin{array}{l}\text { Regina/ } \\
\text { Prince } \\
\text { Albert }\end{array}$ & Edmonton & Vancouver \\
\hline & & & $1883 / 1884$ & & & \\
\hline Food & 108 & 125 & 160 & & & 126 \\
\hline \\
\hline \multirow{3}{*}{$\begin{array}{l}\text { Fuel, Light } \\
\text { HH oper. } \\
\text { Rent }\end{array}$} & 64 & 147 & 147 & & & 143 \\
\hline & & & & & & \\
\hline & & & $1886 / 1887$ & & & \\
\hline Food & 93 & 119 & 125 & & & 146 \\
\hline Clothing & 113 & 89 & 130 & & & 162 \\
\hline Fuel, Light & 93 & 118 & 115 & & & 128 \\
\hline HH oper. & 99 & 105 & $103^{\mathrm{a}}$ & & & 120 \\
\hline \multirow[t]{2}{*}{ Rent } & 83 & 111 & 131 & & & 139 \\
\hline & & & $1889 / 1890$ & & & \\
\hline Food & 98 & 116 & 123 & & & 144 \\
\hline Clothing & 113 & 120 & 140 & & & 194 \\
\hline Fuel, Light & 88 & 129 & 124 & & & 159 \\
\hline HH oper. & 95 & 95 & 139 & & & 113 \\
\hline \multirow[t]{2}{*}{ Rent } & 77 & 116 & 163 & & & 164 \\
\hline & & & $1892 / 1893$ & & & \\
\hline Food & 104 & 123 & 112 & 138 & & 149 \\
\hline Clothing & 118 & 148 & 125 & $169^{\mathrm{b}}$ & & 173 \\
\hline Fuel, Light & 96 & 136 & 122 & 167 & & 117 \\
\hline HH oper. & 100 & 126 & 146 & 179 & & 148 \\
\hline \multirow[t]{2}{*}{ Rent } & 78 & 143 & 159 & & & 139 \\
\hline & & & $1895 / 1896$ & & & \\
\hline Food & 127 & 127 & 129 & 144 & & 161 \\
\hline Clothing & 107 & 135 & 142 & $134^{\mathrm{b}}$ & & 162 \\
\hline Fuel, Light & 117 & 141 & 145 & 161 & & 173 \\
\hline HH oper. & 97 & 118 & 159 & 224 & & 117 \\
\hline \multirow[t]{2}{*}{ Rent } & 80 & 136 & 165 & & & 125 \\
\hline & & & $1899 / 1900$ & & & \\
\hline Food & 111 & 108 & 121 & 140 & & 140 \\
\hline Clothing & 95 & 97 & 100 & $185^{\mathrm{b}}$ & & 113 \\
\hline Fuel, Light & 119 & 117 & 139 & 151 & & 133 \\
\hline HH oper. & 101 & 93 & 159 & 194 & & 142 \\
\hline \multirow[t]{2}{*}{ Rent } & 80 & 130 & 165 & 180 & & 143 \\
\hline & & & $1905 / 1906$ & & & \\
\hline Food & 114 & 109 & 128 & 129 & 143 & 143 \\
\hline Clothing & 95 & 91 & 96 & 167 & 110 & 100 \\
\hline Fuel, Light & 118 & 122 & 133 & 151 & 91 & 128 \\
\hline HH oper. & 111 & 99 & 139 & 157 & $135^{\mathrm{a}}$ & 134 \\
\hline Rent & 75 & 121 & 179 & 150 & 208 & 146 \\
\hline
\end{tabular}




\begin{tabular}{|c|c|c|c|c|c|c|}
\hline & Dorchester & Montreal & Winnipeg & $\begin{array}{c}\text { Regina/ } \\
\text { Prince } \\
\text { Albert }\end{array}$ & Edmonton & Vancouver \\
\hline & & & 1910/1911 & & & \\
\hline Food & 101 & 104 & 108 & & 113 & 132 \\
\hline Clothing & 104 & 100 & 110 & & 113 & 107 \\
\hline Fuel, Light & 108 & 118 & 126 & & 103 & 115 \\
\hline HH oper. & 96 & 102 & 135 & & 136 & 121 \\
\hline Rent & 90 & 150 & $\begin{array}{c}225 \\
1913 / 1914\end{array}$ & 350 & 300 & 238 \\
\hline Food & 112 & 112 & 127 & 138 & 121 & 123 \\
\hline Clothing & 96 & 92 & 92 & 103 & 93 & 94 \\
\hline Fuel, Light & 98 & 104 & 103 & 125 & 81 & 91 \\
\hline HH oper. & 109 & 101 & 121 & 130 & 155 & 120 \\
\hline Rent & 92 & 123 & $\begin{array}{c}269 \\
1916 / 1917\end{array}$ & 346 & 269 & 172 \\
\hline Food & 107 & 111 & 110 & 105 & 97 & 100 \\
\hline Clothing & 91 & 98 & 92 & 105 & 111 & 107 \\
\hline Fuel, Light & 106 & 113 & 125 & 114 & 94 & 101 \\
\hline HH oper. & 108 & 107 & 114 & 131 & 121 & 118 \\
\hline Rent & 75 & 100 & $\begin{array}{c}125 \\
\mathbf{1 9 1 7 / 1 9 1 8}\end{array}$ & 150 & 138 & 75 \\
\hline Food & 107 & 102 & 94 & 97 & 98 & 103 \\
\hline Clothing & 101 & 107 & 109 & 162 & $100^{\mathrm{b}}$ & 100 \\
\hline Fuel, Light & 87 & 98 & 99 & 112 & 80 & 86 \\
\hline HH oper. & 95 & 96 & $81^{\mathrm{a}}$ & 111 & 137 & 99 \\
\hline Rent & 60 & 90 & $\begin{array}{c}125 \\
\mathbf{1 9 1 8} / \mathbf{1 9 1 9}\end{array}$ & 150 & 110 & 83 \\
\hline Food & 122 & 101 & 98 & 107 & 102 & 110 \\
\hline Clothing & 94 & 97 & 125 & $97^{b}$ & 89 & $102^{\mathrm{b}}$ \\
\hline Fuel, Light & 83 & 98 & 93 & 58 & 71 & 72 \\
\hline HH oper. & 82 & 85 & 121 & 96 & 114 & 87 \\
\hline Rent & 74 & 103 & $\begin{array}{c}143 \\
\mathbf{1 9 1 9} / \mathbf{1 9 2 0}\end{array}$ & 200 & 126 & 119 \\
\hline Food & 107 & 99 & 90 & 108 & 97 & 117 \\
\hline Clothing & 98 & 99 & 93 & 104 & 93 & 136 \\
\hline Fuel, Light & 74 & 72 & 79 & 88 & 62 & 78 \\
\hline HH oper. & 114 & 105 & 130 & 133 & 135 & 127 \\
\hline Rent & 70 & 74 & $\begin{array}{c}140 \\
1920 / 1921\end{array}$ & 163 & 158 & 105 \\
\hline Food & 117 & 109 & 105 & 112 & 112 & 119 \\
\hline Clothing & 104 & 108 & 94 & 97 & $86^{\mathrm{b}}$ & 96 \\
\hline Fuel, Light & 60 & 80 & 79 & 61 & 63 & 74 \\
\hline HH oper. & 96 & 122 & 115 & 115 & 127 & 107 \\
\hline Rent & 84 & 100 & 198 & 198 & 209 & 112 \\
\hline
\end{tabular}




\begin{tabular}{lccccc}
\hline & Dorchester & Montreal & Winnipeg & $\begin{array}{c}\text { Regina/ } \\
\text { Prince } \\
\text { Albert }\end{array}$ & Edmonton Vancouv \\
& & & $\mathbf{1 9 2 1 / 1 9 2 2}$ & & \\
Food & 117 & 110 & 112 & 111 & 116 \\
Clothing & 104 & 109 & 102 & 106 & 94 \\
Fuel, Light & 96 & 96 & 86 & 83 & 59 \\
HH oper. & 122 & 93 & 109 & 195 & 135 \\
Rent & 98 & 122 & 207 & 207 & 117 \\
Food & 110 & 108 & 104 & 88 & 121 \\
Clothing & 90 & 95 & $106^{\mathrm{b}}$ & 112 & $92^{\mathrm{b}}$ \\
Fuel, Light & 75 & 78 & 54 & 90 & 90 \\
HH oper. & 112 & 94 & 117 & 131 & 117 \\
Rent & 116 & 137 & 198 & 198 & 112
\end{tabular}

Notes: The note -a- indicates that the household operation component is based on fewer than five goods. The note - $b$ - indicates that the clothing component is based on fewer than eight goods.

B) Inter-temporal price indices by category, Kingston

\begin{tabular}{|l|c|c|c|c|c|}
\hline & Food & Clothing & Fuel \& light & $\begin{array}{l}\text { HH } \\
\text { operation }\end{array}$ & Rent \\
\hline $1883 / 1884$ & 141 & & 137 & & \\
\hline $1886 / 1887$ & 127 & 133 & 126 & 154 & 125 \\
\hline $1889 / 1890$ & 132 & 119 & 111 & 129 & 107 \\
\hline $1892 / 1893$ & 120 & 117 & 112 & 109 & 94 \\
\hline $1895 / 1896$ & 99 & 108 & 91 & 106 & 104 \\
\hline $1899 / 1900$ & 100 & 100 & 100 & 100 & 100 \\
\hline $1905 / 1906$ & 122 & 134 & 96 & 115 & 120 \\
\hline $1910 / 1911$ & 141 & 128 & 101 & 118 & 100 \\
\hline $1913 / 1914$ & 153 & 155 & 117 & 122 & 130 \\
\hline $1916 / 1917$ & 214 & 209 & 135 & 141 & 160 \\
\hline $1917 / 1918$ & 279 & 242 & 216 & 183 & 200 \\
\hline $1918 / 1919$ & 295 & 393 & 247 & 242 & 175 \\
\hline $1919 / 1920$ & 322 & 405 & 249 & 228 & 215 \\
\hline $1920 / 1921$ & 334 & 401 & 337 & 282 & 215 \\
\hline $1921 / 1922$ & 231 & 257 & 271 & 193 & 205 \\
\hline $1922 / 1923$ & 189 & 275 & 166 & 186 & 215 \\
\hline
\end{tabular}


Table 5: Inter-Temporal Penitentiary Consumer Price Indices

A) Inter-temporal food price index (Kingston 1899/1900 = 100)

\begin{tabular}{|l|c|c|c|c|c|c|c|}
\hline & Dorchester & Montreal & Kingston & Winnipeg & $\begin{array}{c}\text { Regina/ } \\
\text { Prince } \\
\text { Albert }\end{array}$ & Edmonton & Vancouver \\
\hline $1883 / 1884$ & 152 & 176 & 141 & 225 & & & 177 \\
\hline $1886 / 1887$ & 118 & 152 & 127 & 159 & & & 186 \\
\hline $1889 / 1890$ & 128 & 153 & 132 & 162 & & & 190 \\
\hline $1892 / 1893$ & 125 & 148 & 120 & 134 & 166 & & 178 \\
\hline $1895 / 1896$ & 125 & 125 & 99 & 127 & 142 & & 159 \\
\hline $1899 / 1900$ & 111 & 108 & 100 & 121 & 140 & & 140 \\
\hline $1905 / 1906$ & 140 & 133 & 122 & 157 & 158 & 175 & 175 \\
\hline $1910 / 1911$ & 142 & 146 & 141 & 152 & & 159 & 186 \\
\hline $1913 / 1914$ & 171 & 171 & 153 & 194 & 211 & 185 & 188 \\
\hline $1916 / 1917$ & 229 & 238 & 214 & 235 & 223 & 207 & 214 \\
\hline $1917 / 1918$ & 299 & 284 & 279 & 263 & 269 & 273 & 288 \\
\hline $1918 / 1919$ & 358 & 298 & 295 & 290 & 316 & 301 & 323 \\
\hline $1919 / 1920$ & 343 & 320 & 322 & 291 & 346 & 311 & 378 \\
\hline $1920 / 1921$ & 389 & 362 & 334 & 350 & 374 & 375 & 396 \\
\hline $1921 / 1922$ & 269 & 253 & 231 & 258 & 256 & & 268 \\
\hline $1922 / 1923$ & 208 & 205 & 189 & 197 & 166 & & 228 \\
\hline
\end{tabular}

B) Inter-temporal penitentiary CPI 1(Kingston 1899/1900 = 100)

\begin{tabular}{|l|c|c|c|c|c|c|c|}
\hline & Dorchester & Montreal & Kingston & Winnipeg & $\begin{array}{c}\text { Regina/ } \\
\text { Prince } \\
\text { Albert }\end{array}$ & Edmonton & Vancouver \\
\hline $1883 / 1884$ & 143 & 179 & 140 & 222 & & & 180 \\
\hline $1886 / 1887$ & 124 & 144 & 130 & 161 & & & 187 \\
\hline $1889 / 1890$ & 117 & 142 & 123 & 165 & & & 189 \\
\hline $1892 / 1893$ & 114 & 149 & 113 & 142 & 178 & & 168 \\
\hline $1895 / 1896$ & 112 & 132 & 102 & 145 & 155 & & 153 \\
\hline $1899 / 1900$ & 102 & 110 & 100 & 131 & 162 & & 136 \\
\hline $1905 / 1906$ & 125 & 130 & 121 & 162 & 175 & 177 & 162 \\
\hline $1910 / 1911$ & 125 & 139 & 125 & 164 & & 181 & 179 \\
\hline $1913 / 1914$ & 149 & 156 & 143 & 207 & 240 & 205 & 178 \\
\hline $1916 / 1917$ & 187 & 202 & 189 & 208 & 217 & 205 & 186 \\
\hline $1917 / 1918$ & 234 & 243 & 243 & 246 & 288 & 248 & 238 \\
\hline $1918 / 1919$ & 288 & 276 & 279 & 312 & 314 & 282 & 292 \\
\hline $1919 / 1920$ & 295 & 284 & 300 & 301 & 346 & 316 & 355 \\
\hline $1920 / 1921$ & 327 & 337 & 316 & 362 & 370 & 372 & 343 \\
\hline $1921 / 1922$ & 251 & 250 & 229 & 286 & 298 & & 254 \\
\hline $1922 / 1923$ & 217 & 224 & 207 & 253 & 249 & & 228 \\
\hline
\end{tabular}


C) - Inter-temporal penitentiary CPI 2 (Kingston 1899/1900 = 100)

\begin{tabular}{|l|c|c|c|c|c|c|c|}
\hline & Dorchester & Montreal & Kingston & Winnipeg & $\begin{array}{c}\text { Regina/ } \\
\text { Prince } \\
\text { Albert }\end{array}$ & Edmonton & Vancouver \\
\hline $1883 / 1884$ & 143 & 179 & 140 & 222 & & & 180 \\
\hline $1886 / 1887$ & 134 & 149 & 136 & 160 & & & 189 \\
\hline $1889 / 1890$ & 126 & 142 & 127 & 166 & & & 183 \\
\hline $1892 / 1893$ & 121 & 149 & 116 & 144 & 181 & & 174 \\
\hline $1895 / 1896$ & 116 & 129 & 102 & 145 & 172 & & 152 \\
\hline $1899 / 1900$ & 106 & 102 & 100 & 130 & 165 & & 136 \\
\hline $1905 / 1906$ & 132 & 124 & 120 & 151 & 175 & 158 & 158 \\
\hline $1910 / 1911$ & 129 & 133 & 129 & 150 & & 153 & 159 \\
\hline $1913 / 1914$ & 152 & 148 & 142 & 166 & 182 & 173 & 163 \\
\hline $1916 / 1917$ & 193 & 200 & 185 & 201 & 206 & 195 & 196 \\
\hline $1917 / 1918$ & 245 & 243 & 239 & 225 & 269 & 254 & 241 \\
\hline $1918 / 1919$ & 302 & 281 & 292 & 321 & 291 & 293 & 293 \\
\hline $1919 / 1920$ & 320 & 300 & 303 & 300 & 337 & 310 & 368 \\
\hline $1920 / 1921$ & 346 & 362 & 330 & 341 & 350 & 354 & 356 \\
\hline $1921 / 1922$ & 258 & 236 & 227 & 243 & 288 & & 258 \\
\hline $1922 / 1923$ & 209 & 200 & 201 & 212 & 212 & & 224 \\
\hline
\end{tabular}

Table 6: Effect of Using Different Weights

A)Kingston Inter-temporal indices using CPI 1 and 1938 weights

$\begin{array}{lrrrrrrrr}\text { Year } & \mathbf{1 8 8 3} & \mathbf{1 8 8 6} & \mathbf{1 8 8 9} & \mathbf{1 8 9 2} & \mathbf{1 8 9 5} & \mathbf{1 8 9 9} & \mathbf{1 9 0 5} & \mathbf{1 9 1 0} \\ \text { Food (Haines weights) } & 141 & 127 & 132 & 120 & 99 & 100 & 122 & 141 \\ \text { Food (1938 weights) } & 148 & 134 & 139 & 116 & 100 & 100 & 129 & 142 \\ \text { Overall (CPI 1 weights) } & 140 & 130 & 123 & 113 & 102 & 100 & 121 & 125 \\ \text { Overall (1938 weights) } & 146 & 133 & 124 & 110 & 102 & 100 & 123 & 123 \\ & & & & & & & & \\ \text { Year } & \mathbf{1 9 1 3} & \mathbf{1 9 1 6} & \mathbf{1 9 1 7} & \mathbf{1 9 1 8} & \mathbf{1 9 1 9} & \mathbf{1 9 2 0} & \mathbf{1 9 2 1} & \mathbf{1 9 2 2} \\ \text { Food (Haines weights) } & 153 & 214 & 279 & 295 & 322 & 334 & 231 & 189 \\ \text { Food (1938 weights) } & 166 & 224 & 279 & 314 & 344 & 364 & 255 & 211 \\ \text { Overall (CPI 1 weights) } & 143 & 189 & 243 & 279 & 300 & 316 & 224 & 207 \\ \text { Overall (1938 weights) } & 146 & 188 & 237 & 276 & 299 & 320 & 230 & 215\end{array}$

Note: 1938 food weights from DBS (1941, p. 63). Overall weights derived from DBS (1941, p. 26): food $=39$, fuel $=9$, clothing $=15$, shelter $=25$, household operation $=12$. 
B) Inter-regional relative prices using different weights, $1886 / 87$ and 1922/23

$($ Kingston $=100)$

$\begin{array}{ccccc}\text { Dorchester } & \text { Montreal } & \text { Winnipeg } & \begin{array}{l}\text { Regina/ } \\ \text { Prince } \\ \text { Albert }\end{array} & \text { Vancouver } \\ & & & & \\ 93 & 119 & 125 & & 146 \\ 93 & 118 & 128 & & 197 \\ 95 & 111 & 124 & & 143 \\ 95 & 111 & 123 & & 142 \\ & & & & \\ 110 & 108 & 104 & 88 & 121 \\ 104 & 112 & 106 & 93 & 119 \\ 105 & 108 & 122 & 120 & 110 \\ 105 & 110 & 127 & 126 & 110\end{array}$

Table 7 -Other Price Indices

A) Retail Food Prices, Emery-Levitt (Toronto, Dec. $1900=100$ )

\begin{tabular}{|l|c|c|c|c|c|}
\hline & Saint John & Montreal & Toronto & Winnipeg & Vancouver \\
\hline 1900 & 105 & 119 & 100 & 116 & 128 \\
\hline 1905 & 119 & 134 & 111 & 121 & 138 \\
\hline 1910 & 145 & 135 & 137 & 147 & 169 \\
\hline 1913 & 159 & 155 & 155 & 158 & 166 \\
\hline 1916 & 202 & 195 & 222 & 197 & 194 \\
\hline 1917 & 255 & 247 & 254 & 233 & 242 \\
\hline 1918 & 287 & 256 & 266 & 254 & 280 \\
\hline 1919 & 298 & 254 & 273 & 301 & 301 \\
\hline 1920 & 301 & 273 & 257 & 272 & 281 \\
\hline 1921 & 225 & 202 & 208 & 198 & 217 \\
\hline 1922 & 215 & 195 & 197 & 189 & 211 \\
\hline
\end{tabular}


B) Nineteenth and Early Twentieth Century Price Indices $(1900=100)$

\begin{tabular}{|c|c|c|c|c|c|c|c|c|c|}
\hline Year & $\begin{array}{l}\text { Implicit } \\
\text { Price } \\
\text { Index }\end{array}$ & $\begin{array}{l}\text { Food } \\
\text { "family } \\
\text { budget" }\end{array}$ & $\begin{array}{l}\text { Food, } \\
\text { Kingston }\end{array}$ & $\begin{array}{l}\text { Grains } \\
\text { and } \\
\text { Flour }\end{array}$ & $\begin{array}{l}\text { Animals } \\
\text { and meats }\end{array}$ & $\begin{array}{l}\text { Fuel and } \\
\text { Light, } \\
\text { Kingston }\end{array}$ & $\begin{array}{l}\text { Fuel and } \\
\text { Lighting }\end{array}$ & Clothing & Building \\
\hline & 1 & 2 & 3 & 4 & 5 & 6 & 7 & 8 & 9 \\
\hline 1883 & 112 & & 130 & 148 & 123 & 100 & & & \\
\hline 1886 & 100 & & 107 & 111 & 92 & 103 & & & \\
\hline 1889 & 106 & & 111 & 126 & 99 & 100 & 107 & & 94 \\
\hline 1892 & 104 & & 108 & 116 & 97 & 102 & 106 & & 84 \\
\hline 1895 & 91 & & 91 & 111 & 87 & 89 & 96 & & 81 \\
\hline 1898 & 98 & & 105 & 112 & 87 & 90 & 93 & & 76 \\
\hline 1900 & 100 & 100 & 100 & 100 & 100 & 100 & 100 & 100 & 100 \\
\hline 1905 & 109 & 109 & & 134 & 106 & & 104 & 108 & 94 \\
\hline 1910 & 122 & 127 & & 137 & 145 & & 102 & 114 & 101 \\
\hline 1913 & 134 & 134 & & 134 & 156 & & 117 & 113 & 91 \\
\hline 1916 & 149 & 160 & & 191 & 191 & & 132 & 141 & \\
\hline 1919 & 219 & 253 & & 299 & 325 & & 235 & 224 & \\
\hline 1920 & 254 & 292 & & 355 & 303 & & 308 & 273 & \\
\hline 1922 & 205 & 190 & & 178 & 199 & & 261 & 188 & \\
\hline
\end{tabular}

Sources: (1) Urquhart (1993), pp. 24-25. (2) Urquhart and Buckley (1965), J 129. (3) and (6), Barnett (1963) p. 9. (4), (5) and (7), HSC J3,5, 25, with 1890 price used for 1889 in (7).. (8) calculated from Bertram and Percy (1979), p. 306. (9), calculated from Coats Report (1915), Vol. II, pp. 52-3, 58-63. average of relative prices of common bar iron, galvanized iron sheets, pine lumber, N.B. spruce deals, cement, cut nails, raw linseed oil, turpentine, and varnish, with 1890 prices used for 1889. 
Table 8 Penitentiary / Retail price ratios

Saint John

Montreal

Kingston

Winnipeg

Vancouver

Saint John

Montreal

Kingston

Winnipeg

Vancouver

Saint John

Montreal

Kingston

Winnipeg

Vancouver

Saint John

Montreal

Kingston

Winnipeg

Vancouver

Saint John

Montreal

Kingston

Winnipeg

Vancouver

Saint John

Montreal

Kingston

Winnipeg

Vancouver

Saint John

Montreal

Kingston

Winnipeg

Vancouver
Beef

Flour

$1889 / 1890$

53

67

64

50

44

36

33

45

39

33

36

41

31

30

41

35

40

35

37

51

41

45

37

32

45

22

64

33

46

48

22

24

32

26

24

89

100

99

88

108

$1899 / 1900$

100

55

92

95

57

1910/1911

58

74

61

89

58

1913/1914

95

86

63

66

80

$1917 / 1918$

87

91

74

84

79

$1919 / 1920$

85

88

89

76

83

$1922 / 1923$

$\begin{array}{lcc}72 & 55 & 80 \\ 58 & 50 & 77 \\ 64 & 90 & 84 \\ 62 & 144 & 84 \\ 63 & 70 & 90\end{array}$

\section{Butter}

68

89

94

170

100

69

63

68

68

63

72

75

87

67

90

$80 \quad 90$

76

89

92

93

79

73

93

84

91

91

78

87

88

77

73

80

77

84

84

90

A value of 100 indicates equality of prices. Retail prices quotes for 1889 from Minister of Agriculture's Report for 1889/90, for 1900-1913 from the Coats Report (1915, Vol. 1), 191722 from $L G$. Mean used if price range given. 1900 on, sirloin steak used for beef, creamery prints for butter, potatoes per $90 \mathrm{lb}$ bag. Toronto price for sirloin steak used for Kingston, December 1910. 
Figure 1: Food price index, 1883-1923 (Kingston 1899=100)

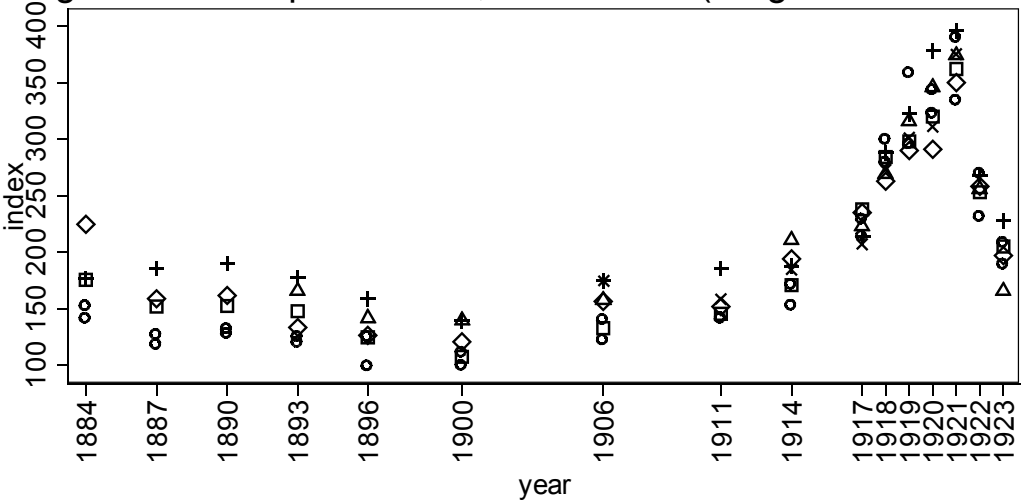

\begin{tabular}{clcl}
$\circ$ & Saint John & $\square$ & Montreal \\
$\circ$ & Kingston & $\diamond$ & Winnipeg \\
$\Delta$ & Regina/PA & $\times$ & Edmonton \\
+ & Vancouver & & \\
\hline
\end{tabular}

Figure 2: CPI 1, 1883-1923 (Kingston 1899=100)

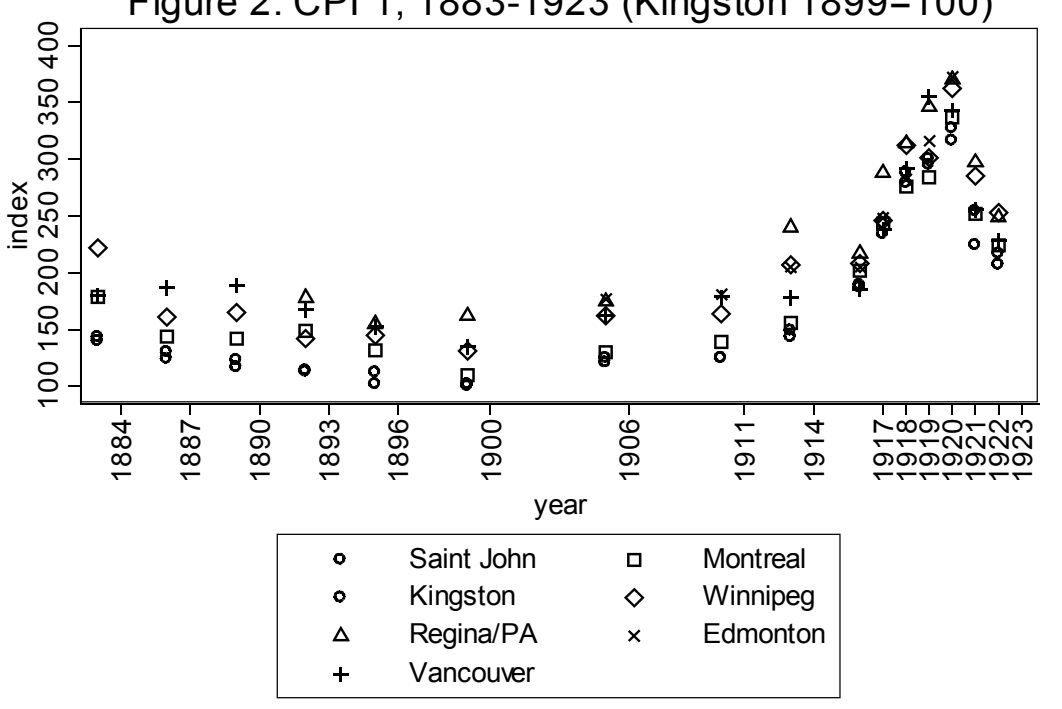


Figure 3: CPI 2, 1883-1923 (Kingston 1899=100)

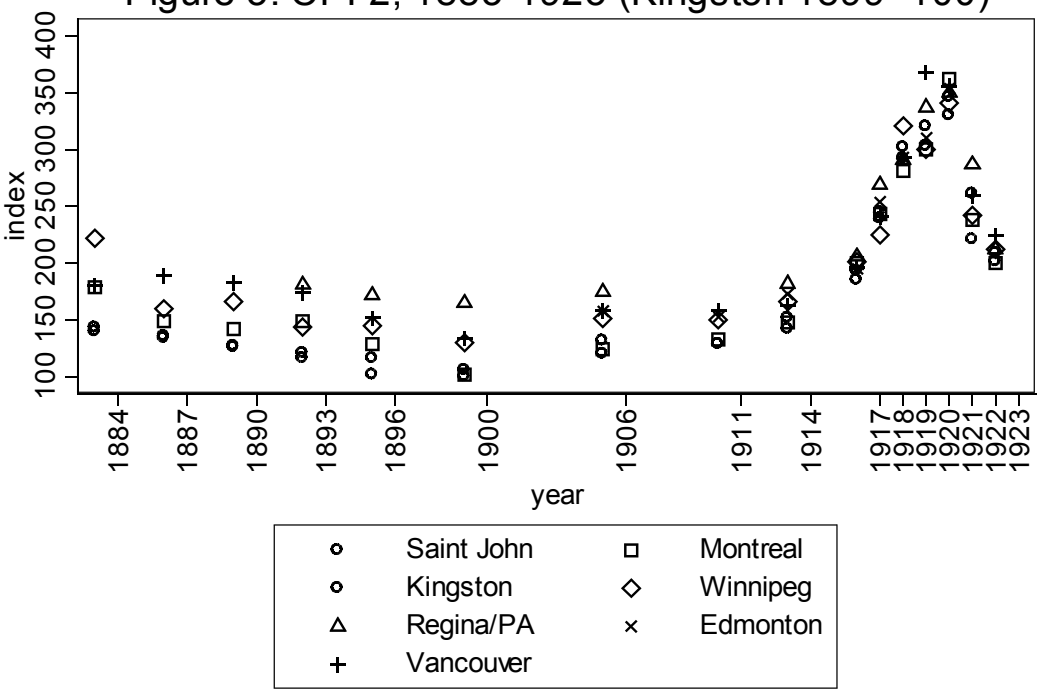

Figure 4: Coefficient of variation, food index

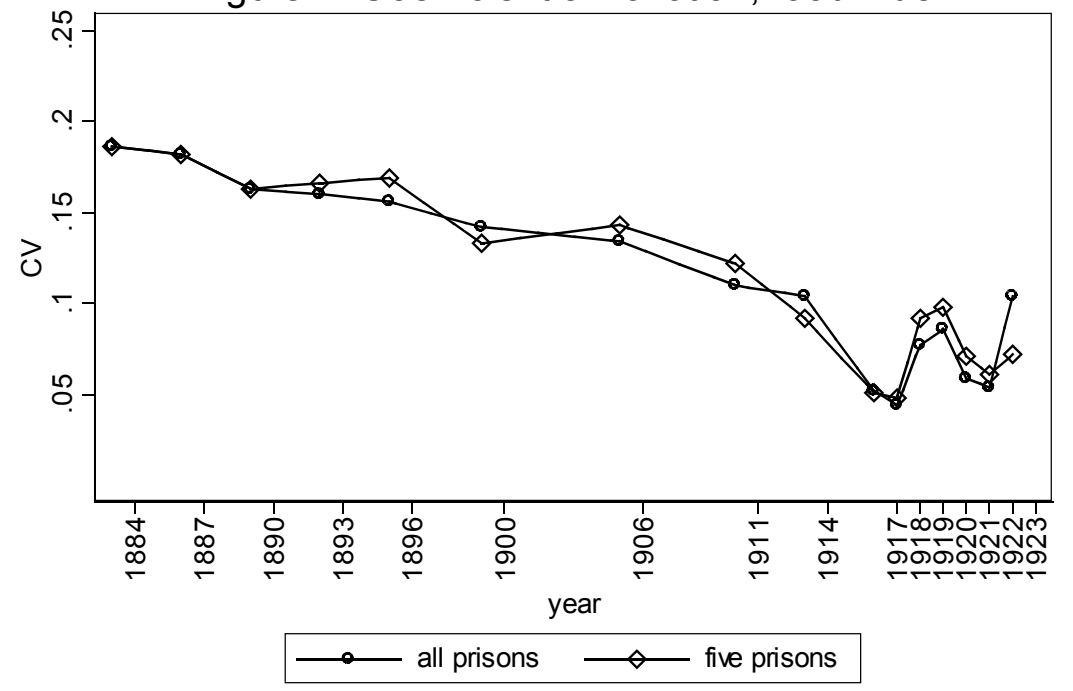


Figure 5: Coefficient of variation, CPI 1

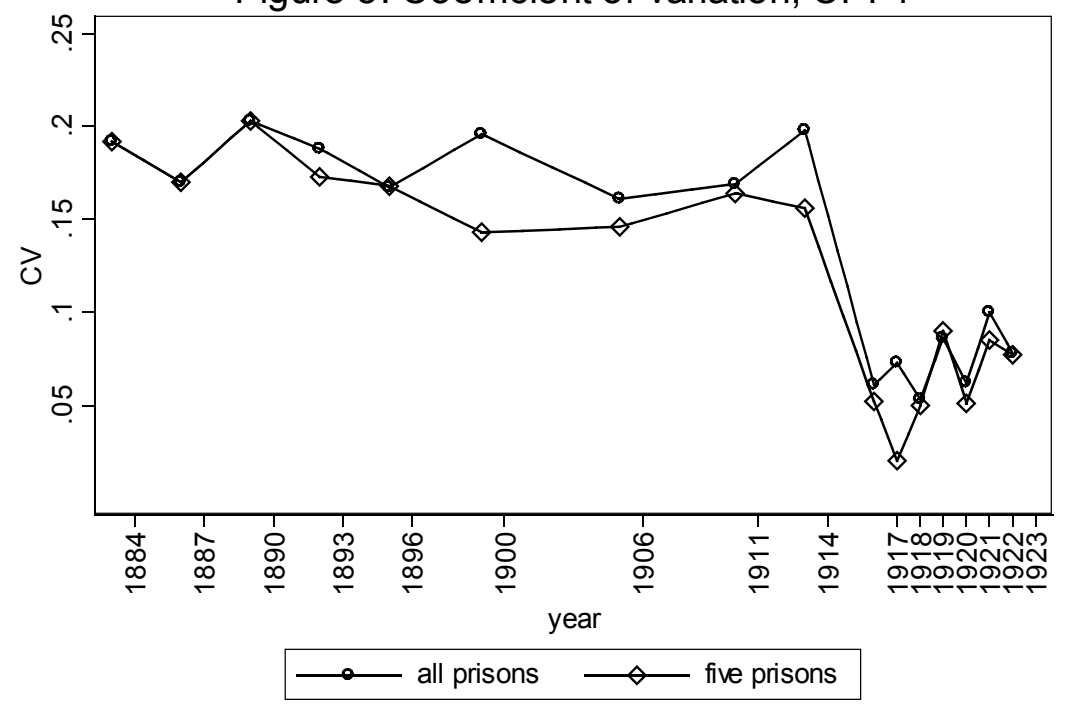

Figure 6: Coefficient of variation, CPI 2

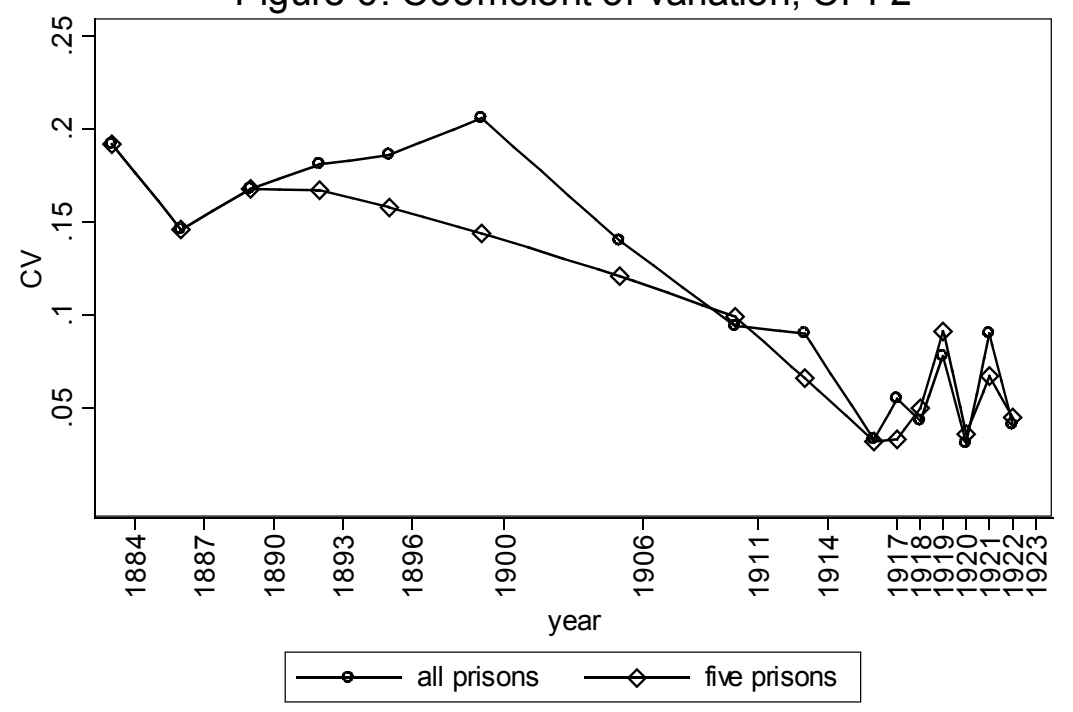




\section{Appendix}

\section{Price sources}

Canadian federal penitentiary expenditures are included in the Justice Department sub-section of the Report of the Auditor General of Canada (AGR). We have taken data from 16 years of the AGR: 1883/84, 1886/87, 1889/90, 1893/94, 1895/96 1899/1900, 1905/06, 1910/1911, 1913/14, 1916/17, 1917/18, 1918/19. 1919/20, 1920/21, 1921/22, and 1922/1923. Prior to 1906, reports are for the twelve months ending June $30^{\text {th }}$. Beginning in 1907, reports are for a twelve month period ending March $31^{\text {st }}$. The Reports were published in the series of Sessional Papers the following year. Therefore, the 1900 Report of the Auditor General details expenditures from July $1^{\text {st }} 1899$ to June $30^{\text {th }} 1900$, and appears as part of the Sessional Papers of 1901.

From the late 1880s until 1915/16, Reports of the Inspector of Penitentiaries (IPR) gave details on expenditures, usually by purpose (rations, officers' uniforms, prison farm, hospital and so on). These reports normally listed very small purchases not itemized in the AGR. We use the IPR to supplement price data from the AGR. When items listed in Table 2 were absent from both AGR and IPR for a penitentiary, we searched for prices from other institutions in reasonably nearby locations as a replacement, and for penitentiary prices in adjacent years. For years from 1916/17 on, we used only information for that year. The main additional sources we have used are records of the Department of Militia and Defence, the Department of Public Works, the North West Mounted Police, and Indian Affairs. For Kingston, we have used records of the Ontario Hospital (the provincial mental hospital). (We have been unable to find similar published reports for mental hospitals in other provinces). Goods are excluded from the index when we are unable to find a reference price for Kingston.

For each prison, we have added a second series of coal prices, based on information in the Department of Public Works "Dominion Buildings Maintenance" section of the AGR. For every year from 1886/7 onwards, we have included prices for coal purchased by the Sussex N.B. post office, the Montreal Post Office (in later years, the Post Office Annex and Postal Stations A to C), the Kingston Post Office, the Winnipeg Post Office, The Regina Post Office, the Prince Albert Post Office, the Edmonton Post Office, and the New Westminster Dominion Building. As with the penitentiary coal price series, we weighted the prices by the quantities purchased. Some coal, wood, and coal oil prices for the Regina Jail and Court House, and the Prince Albert Jail and Court House, are included in this section of the AGR, rather than the Justice Section. For some early years, expenses on construction and repair of penitentiary buildings are also listed under Public Works, not Justice.

The First World War and the AGR: During and shortly after the First World War, virtually every government department had its work affected by the war. A substantial extra section was added to the end of each AGR (usually called section ZZ), with what were considered to be "war-related" expenses for each department. At least for the Departments of Militia and Defence, and the Naval Service, it seems to us pretty arbitrary which expenses appeared in the department's "regular" section, and which appeared as special war appropriations. Users of the AGR in this period must be sure to check both sections. 
Abbreviations for Sources:

IA: Department of Indian Affairs

(RI - Regina Industrial School)

(ES - Elkhorn Industrial School)

Agencies, and other industrial schools described by full name.

ID: Department of the Interior

KA: Ontario Hospital, Kingston [Records drawn from Ontario Public Accounts, and from Annual Report of Inspector of Prisons and Public Charities.]

MD: Department of Militia and Defence

(MD A, B, or C. These are batteries. "A" battery is in Kingston, "B" in Quebec City, "C" in Victoria, B.C.)

(MD also stands for Military Districts, which bought a lot of supplies, especially during the First World War. At this time, MD 3 was Eastern Ontario, 4 around Montreal, 6 Nova Scotia, 7 New Brunswick, 10 Manitoba, 11 British Columbia, 12 Saskatchewan, 13 Alberta)

(MPWB - Military Properties, Works and Buildings, various locations)

(PPFPS - pay of permanent force, provisions and supplies, various locations. VE denotes "Victoria and Esquimalt")

(RCHA - Royal Canadian Horse Artillery, Kingston)

(RCMR - Royal Canadian Mounted Rifles, Winnipeg)

(RMC - Royal Military College, Kingston)

MF: Department of Marine and Fisheries

(DS - Dominion Steamer)

(ML -- Maintenance of Lights. In early years, ML expenditures are listed under Public Works.)

NS: Naval Service

(RNC - Royal Naval College, Halifax and Victoria)

(dockyards in Halifax and Esquimalt (some aspects of dockyard expenditure are listed under Public Works.))

NWMP: North West Mounted Police (in later years, RNWMP or RCMP)

PW: Department of Public Works. This department was responsible for construction and maintenance of public buildings, harbours, dredging of rivers, experimental farms, and at least in some years, maintenance of lighthouses.

SCR: Department of Soldiers' Civil Re-establishment (this appears to replace the ISC Invalided Soldiers' Commission) 


\section{Substitute and Missing Prices:}

$\underline{1883 / 1884}$

Clothes: Not included.

Flour: Kingston price an average of 1883 and 1884 prices from Kingston Asylum, in Ontario Report of Inspector of Prisons and Public Charities (KA).

Barley: No price for Manitoba or British Columbia.

Mutton: Not included.

Bacon/Pork: Bacon not included. No pork price for British Columbia.

Butter: Dorchester price from 1884-85.

Milk: No price for Dorchester or British Columbia.

Beans: No price for St.Vincent de Paul or British Columbia. Kingston price from 1884-85.

Potatoes: No price for British Columbia

Peas: No price for Dorchester or British Columbia.

Prunes: Not included.

Eggs: No price for Dorchester or British Columbia. Manitoba price from 1884-85.

Molasses: Not included.

Coffee: Not included.

Soap: No price for St. Vincent de Paul. Manitoba price from NWMP, Regina. British Columbia price from 1884-85.

Wood: No price for British Columbia. Dorchester price from MD, $8^{\text {th }}$ Military District, Southern New Brunswick.

Building Materials: Not included.

\section{$\underline{1886 / 1887}$}

Braces: Kingston price from 1887-88. Manitoba price from 1887-88. No price for St

Vincent de Paul and Dorchester. [In some years, prisons purchased suspenders, not braces. We assumed that suspenders and braces were interchangeable.]

Canvas: No price for St.Vincent de Paul.

Cotton: No price for St.Vincent de Paul. [These are various kinds of apparently light weight cottons, including grey cotton, white cotton, and print.]

Denim: Kingston only

Linen: Dorchester and St. Vincent de Paul prices from 1887-88. No price for Manitoba.

[Linen was purchased for both bedding and clothing.]

Lining: Kingston, St.Vincent de Paul, and Dorchester prices from 1887-88. [Lining of various grades and weights purchased, both for officers' uniforms and for freedom suits.]

Serge: Kingston, St.Vincent de Paul, Dorchester, and Manitoba prices from 1887-88. [Mainly used for officers' uniforms, and for freedom suits.]

Shirting: Kingston only, 1885/6. [In some years, described as galatea shirting, or just galatea.]

Silesia: except for Kingston, prices from 1887/8.

Sole Leather: All prices from 1885/6 or 1887/8. Includes price quotations for unspecified kinds of leather measured in pounds. (Most other grades of leather were bought by the foot.) We used this definition throughout.

Straw Hats: prices from 1885/6 and 1887/8. [For farm work.]

Ticking: Manitoba price from 1887-88, BC price from 1885/6. No price for St.Vincent de Paul or Dorchester. 
Tweed: British Columbia price from 1887-88.

Yarn: no price for St. Vincent de Paul. Other prices from 1885/6 and 1887/8

Bacon/Pork: Pork prices not used. St.Vincent de Paul price from Public Works, maintenance of lights (ML) "below Quebec." British Columbia price from Indian Affairs (IA), "supplies and presents." No price for Dorchester.

Barley: Manitoba price from IA, Manitoba and North West Territories, "farm maintenance." Beans: St.Vincent de Paul price from 1887-88. British Columbia price from IA, "supplies and presents".

Coffee: St.Vincent de Paul price from ML, "below Quebec." Dorchester price from ML, Nova Scotia. No price for British Columbia.

Currants and Raisins: Kingston, Manitoba, and British Columbia prices from 1887-88.

Eggs: No price for Dorchester.

Flour: Kingston price from KA.

Lard: Kingston and St.Vincent de Paul prices from 1887-88. No price for Dorchester or British Columbia.

Molasses: No price for Kingston, Manitoba, or British Columbia.

Mutton: No price for Kingston, Dorchester, or British Columbia.

Pepper: British Columbia price from 1887-88.

Potatoes: British Columbia price from IA. No price for Dorchester.

Peas: British Columbia price from 1887-88.

Rice: St.Vincent de Paul price from 1887-88.

Salt: Kingston price from 1887-88. No price for St.Vincent de Paul.

Soap: St.Vincent de Paul price from 1887-88. Kingston price 1885/6.

Wood: Dorchester price from MD, "A" infantry school, Fredericton. British Columbia price from PW, dredging, "dredging generally".

Cement: repairs to Ottawa public buildings, as well as prison price for Kingston. Dorchester: PEI railway and maintenance of lights, Nova Scotia. No price for Manitoba or B.C.

Iron: Rideau River improvements and Ottawa Parliament Buildings for Kingston. Harbours and rivers, and Quebec Public buildings for St. Vincent de Paul. PEI railway, and harbours and rivers, NB and NS for Dorchester

Lumber: Harbours and rivers in western Quebec, and penitentiary, for St. Vincent de Paul. PEI railway, and harbours and rivers in NB and NS for Dorchester. Pen and Victoria immigration building for BC.

Nails: No price for St. Vincent de Paul or Manitoba. PEI railway for Dorchester. Victoria immigration building for BC.

Oils: Ottawa buildings for Kingston. ML for St. Vincent de Paul. Pen and ML for Dorchester. No price for B.C.

Japan Varnish: no price for St. Vincent de Paul, Manitoba or B.C. PEI railway for Dorchester.

Turpentine: Not included.

$\underline{1889 / 1890}$

Denim: not included

Linen: No price for Manitoba.

Lining: No price for Manitoba.

Shirting: Kingston only

Yarn: no price for St. Vincent de Paul or B.C.

Flour: Kingston price an average of 1889 and 1890 prices from KA. 
Mutton: No price for Dorchester or British Columbia

Bacon/Pork: No bacon price for St.Vincent de Paul, Dorchester, or Manitoba. British

Columbia bacon prices from IA, Victoria office, Fraser agency, and Kamloops agency. No pork price for British Columbia.

Milk: No price for Dorchester, Manitoba, or British Columbia.

Beans: British Columbia prices from IA, Kamloops industrial school.

Potatoes: British Columbia price from MD, "C" battery, Victoria (MD C).

Peas: No price for Dorchester. British Columbia price from 1890-91.

Prunes: Not included.

Currants and Raisins: St.Vincent de Paul price from 1890-91.

Eggs: No price for Dorchester. St.Vincent de Paul price from 1890-91.

Molasses: Not included.

Coffee: No price for Dorchester. British Columbia prices from IA, Fraser and Kamloops agencies, Kamloops industrial school.

Wood: British Columbia price from MD C.

Cement: Quebec Citadel for St. Vincent de Paul. Sussex Post Office for Dorchester. No price for Manitoba or B.C.

Iron: Beauharnois Canal and pen for St. Vincent de Paul. No price for Manitoba or B.C.

Lumber: contract price for 1890/91 for Dorchester.

Nails: all but Dorchester, contract price for 1890/91. Dorchester, MD, Fredericton Infantry.

School.

Oils: PW St. Lawrence ship channel and contract price for St. Vincent de Paul.

Japan: no price for Dorchester or B.C.

Turpentine: contract price for 1890-1 for Manitoba.

$\underline{1892 / 93}$

Braces: Regina price from Regina Industrial School. Manitoba price from 1893-94.

Canvas: No price for Regina.

Denim: Not included.

Linen: No price for Regina.

Lining: No price for Regina. British Columbia price from 1893-94.

Serge: No price for Regina.

Shirting: Kingston only.

Silesia: no price for B.C. or Regina.

Ticking: Regina price from Regina Industrial School. St.Vincent de Paul price from 1893-94.

Yarn: no price, St. Vincent de Paul or Regina.

Flour: Regina price from IA, Regina Industrial School (RI), 1894.

Barley: No price for British Columbia.

Fish: Regina price from RI.

Mutton: No price for Dorchester or Regina.

Bacon/Pork: No pork prices used. No bacon prices for St.Vincent de Paul, Dorchester, or Manitoba.

Milk: No price for Dorchester, Manitoba, British Columbia, or Regina.

Beans: Regina price from RI.

Potatoes: Manitoba price from MD, Winnipeg Mounted Infantry School. B.C. price from MD C.

Peas: No price for Regina. British Columbia price from 1893-94.

Prunes: Not included. 
Currants and Raisins: Regina price from RI, 1894.

Vinegar: No price for Regina.

Pepper: Regina price from NWMP, Regina.

Salt: Regina price from RI.

Eggs: No price for Dorchester. Manitoba price from 1893-94.

Lard: Regina price from RI.

Molasses: Not included.

Sugar: Regina price from RI.

Coffee: No price for Dorchester.

Soap: Regina Price from NWMP, Regina.

Tobacco: Regina Price from NWMP, Regina.

Wood: Dorchester price from MD, Sussex (New Brunswick) Camp, Annual Drill. British

Columbia Price from MD C.

Cement: Rideau canal repairs for Kingston. Jail and NWMP barracks for Regina.

Iron: Pen and Ottawa experimental farm for Kingston. 1892/3 and 1893/4 prices for St.

Vincent de Paul, Dorchester, B.C. and Regina.

Lumber: 1892/3 and 1893/4 prices used for Kingston and St. Vincent de Paul.

Nails: PW Central Experimental Farm, Ottawa, 1893/4 for Kingston. 1893/4 for St. Vincent de Paul.

Oils: $1892 / 3$ and 1893/4 for St. Vincent de Paul

Japan Varnish: No price for Dorchester or Regina. 1893/4 for Manitoba and B.C.

Turpentine: NWMP Regina for Regina.

$\underline{1895 / 1896}$

Canvas: No price for Regina.

Cotton: No price for St.Vincent de Paul or British Columbia.

Denim: Not included.

Linen: No price for Manitoba or Regina.

Lining: No price for Regina.

Shirting: Kingston only.

Silesia: No price for Regina.

Ticking: No price for St. Vincent de Paul or Regina.

Tweed: No price for Regina.

Yarn: No price for Regina.

Flour: Manitoba price from IA, Birtle agency. Regina price from NWMP, Regina.

Barley: St.Vincent de Paul price from Marine and Fisheries (MF), Quebec Steamer "Druid".

Rice: Regina price from NWMP, Regina.

Fish: No price for Regina.

Mutton: No price for Dorchester or Regina.

Bacon/Pork: No pork prices used. St.Vincent de Paul price from MF, Fisheries Protection

Service, steamer "Constance." Dorchester Price from MF, Halifax steamers. Manitoba price from IA, Birtle Agency. Regina price from NWMP Regina.

Milk: No price for Manitoba or Regina. Dorchester price from MF, various steamers. British Columbia price from MF, Victoria steamer "Quadra"

Beans: Regina price from NWMP Regina.

Potatoes: Manitoba price from MD, "B” Squadron, Winnipeg. British Columbia Price from 1896-97.

Peas: No price for Regina. Dorchester price from MF, Charlottetown steamer "K". 
Manitoba price from 1896-97.

Prunes: Not included.

Currants and Raisins: No price for St.Vincent de Paul or British Columbia.

Vinegar: No price for Regina.

Molasses: No price for British Columbia.

Coffee: Dorchester price from MF, North Sydney and Halifax steamers.

Soap: Regina Price from NWMP, Regina.

Tobacco: St.Vincent de Paul, Dorchester, and Manitoba price from 1896-97.

Wood: Dorchester price from various quotes in MF and MD. British Columbia Price from

MF, Fraser River fish hatchery.

Cement: Regina Government House for Regina.

Iron: 1893/4 price for B.C. IA Battleford and Qu'Appelle industrial Schools 1893/4 for

Regina.

Lumber: 1895/6 and 1896/7 prices for Kingston. 1896/7 maintenance of lights NB and

Tracadie Lazaretto 1895/6 for Dorchester

Nails: repairs to St. Lawrence ship channel 1896/7 for St. Vincent de Paul. 1896/97 for B.C..

Battleford Indian Agent's house for Regina.

Oils: PW Victoria Harbour for B.C.

$\underline{1899 / 1900}$

Regina and Prince Albert Jail prices are used interchangeably in this year.

Canvas: No price for Regina.

Denim: Not included.

Straw Hats: No price for Dorchester or Regina. British Columbia price from 1900-01.

Linen: No price for Manitoba or Regina.

Lining: No price for St. Vincent de Paul or Regina. Kingston price from 1900-01.

Dorchester price from 1900-01.

Shirting: No price for Manitoba.

Silesia: No price for Regina.

Ticking: No price for Regina. Dorchester and British Columbia price from 1900-01.

Tweed: No price for Regina.

Flour: Regina price from NWMP, Regina.

Barley: Manitoba price from 1900-01.

Rice: Dorchester price from 1900-01. British Columbia price from PW, Vancouver. Regina price from NWMP, Regina.

Mutton: No price for Regina. British Columbia price from PW, Vancouver. Manitoba price from ID, Winnipeg, and from MD, Winnipeg.

Bacon/Pork: No pork price for Manitoba or British Columbia. Regina pork price from 190001. No bacon price for St.Vincent de Paul, or Dorchester.

Milk: No price for Manitoba. Dorchester price from MF, Saint John. British Columbia price from 1900-01.

Beans: No price for Regina.

Potatoes: Manitoba price from IA, Winnipeg. British Columbia price from PW, Vancouver Prunes: Not included.

Currants and Raisins: Regina price from 1900-01.

Vinegar: No price for Regina.

Lard: Regina price from NWMP, Regina.

Tea: Regina price from NWMP, Regina. 
Soap: Regina price from 1900-01.

Tobacco: St. Vincent de Paul price from 1900-01. Dorchester price from Department of the Interior (1900), An official handbook of information relating to the Dominion of Canada.

(Government Printing Bureau: Ottawa). British Columbia prices from NWMP, Vancouver and PW, Vancouver. Regina price from NWMP, Regina.

Wood: No price for Dorchester or British Columbia.

Cement: PW Kingston Graving Docks for Kingston price. ML and Graving Dock Esquimalt for B.C. NWMP Regina, and IA RI for Regina price.

Iron: No price for Regina. ML for B.C. price.

Lumber: ML N.B. for Dorchester price. Jail and IA RI price for Regina.

Nails: IA Brandon Industrial School price for Manitoba.

Oils: Esquimalt Graving Dock for B.C. price. NWMP Regina, and IA RI for Regina price.

Japan Varnish: No price for St. Vincent de Paul, Manitoba or B.C.

\section{$\underline{1905 / 1906}$}

Regina and Prince Albert Jail prices are used interchangeably in this year.

Braces: No price for Manitoba.

Canvas: No price for Regina.

Denim: No price for B.C., Regina or Alberta.

Straw hats: Alberta price from 1906-07

Linen: No price for Manitoba. Kingston price from 1906-07 and KA 1906 (calendar year).

Alberta price from 1906-07.

Lining: No price for Regina. Alberta price from 1906-07.

Serge: No price for Regina. British Columbia and Alberta price from 1906-07.

Shirting: Regina price from IA, Battleford Agency. Kingston from 1906-07

Ticking: Kingston price from 1906-07 and KA 1906. St.Vincent de Paul price from MF

Dominion Steamer (DS) “Aberdeen.” Dorchester price from ML, Halifax. Alberta price from 1906-07.

Tweed: No price for British Columbia or Regina. Alberta price from 1906-07.

Sole leather: No price for Regina. Alberta price from 1906-07.

Yarn: No price for Alberta.

Bacon/Pork: Pork prices not used. St.Vincent de Paul price from DS “Aberdeen”.

Dorchester price from DS in Saint John and Pictou. Manitoba price from MD, Royal

Canadian Mounted Rifles (RCMR), Winnipeg. Regina price from IA, Assiniboine and

Battleford agencies. Alberta price from 1906-07 and IA, Edmonton agency.

Barley: No price for Manitoba. Alberta price from 1906-07.

Beans: Regina price from RNWMP, Regina. Alberta price from 1906-07

Beef: Alberta price from 1906-07, RNWMP, Edmonton, and IA, Edmonton agency.

Butter: Regina price from RNWMP, Prince Albert. Edmonton price from 1906-07 and IA,

Edmonton agency.

Tobacco: No price for Dorchester, British Columbia, or Regina. Alberta price from 1906-07.

Coffee: No price for Alberta. Kingston price from MD, Royal Canadian Horse Artillery

(RCHA), Kingston. Manitoba price from 1906-07, Royal Canadian Mounted Rifles (RCMR)

Winnipeg and IA, Elkhorn Industrial School (ES).

Currants and Raisins: No price for Regina or Alberta. Manitoba price from 1906-07.

Eggs: No price for Regina. Alberta price from 1906-07.

Fish: No price for Regina. Manitoba price from 1906-07 and ES. Alberta price from 190607. 
Flour: Regina price from IA, Assiniboine and Battleford agencies, RNWMP, Regina and Prince Albert suppliers. Alberta price from 1906-07, IA Edmonon agency, and RNWMP Edmonton.

Lard: No price for Regina. Manitoba price from ES. Alberta price from 1906-07. Milk: No price for Regina. Dorchester price from DS "Pictou" and MD, Halifax detatchment. Manitoba price from ES and RCMR, Winnipeg. British Columbia price from (DS) "Quadra". Alberta price from 1906-07.

Molasses: No price for British Columbia. Kingston price from KA 1906. Alberta price from 1906-07.

Mutton: No prices for Regina or Alberta. Kingston price from RCHA, Kingston. St.Vincent de Paul price from 1906-07 and MD, St.Jean. Manitoba price from ES and RCMR, Winnipeg. British Columbia price from DS "Quadra."

Oatmeal: Alberta price from 1906-07.

Pepper: Regina price from RNWMP, Regina. Alberta price from 1906-07.

Potatoes: Manitoba price from RCMR, Winnipeg, and 1906-07. Regina price from

RNWMP, Regina. Alberta price from RNWMP, Edmonton and 1906-07.

Peas: No price for Regina. Alberta price from 1906-07.

Prunes: Manitoba price from 1906-07 and ES. Regina price from RNWMP, Regina and Prince Albert. Alberta price from 1906-07.

Rice: Alberta price from 1906-07 and IA, Edmonton agency.

Salt: Alberta price from IA, Edmonton agency.

Sugar: Alberta price from 1906-07 and RNWMP, Edmonton.

Tea: Alberta price from 1906-07, RNWMP, Edmonton, and IA, Edmonton agency.

Vinegar: No price for Regina. Alberta price from 1906-07.

Soap: British Columbia price from 906-07. Alberta price from IA, Edmonton agency.

Coal: Alberta price from 1906-07, IA, Edmonton agency, and RNWMP, Edmonton.

Coal oil: Kingston price from RCHA, Kingston. St.Vincent de Paul price from 1906-07, MD

for St.Jean and Quebec, and MF, St.Lawrence ship canal. Alberta price from 1906-07, IA, Edmonton agencies, and RNWMP, Edmonton.

Wood: Dorchester price from MD and ML, various. Saskatchewan price from IA, Battleford agency and RNWMP Prince Albert. Alberta price from IA, Edmonton agency.

Cement: No price for Alberta.

Iron: No price for Alberta.

Lumber: IA Calgary Industrial School, RNWMP Fort Saskatchewan and Calgary for Alberta price. Regina and Prince Albert RNWMP prices for Regina.

Nails: RNWMP Fort Saskatchewan prices for Alberta. RNWMP Regina and IA RI for

Regina prices.

Oils: RNWMP Fort Saskatchewan and Calgary prices for Alberta. RNWMP Regina prices

for Regina.

Japan Varnish: Not included.

Turpentine: RNWMP Regina for Regina price.

$\underline{1910 / 1911}$

Braces: No price for Alberta.

Denim: No price St. Vincent de Paul or B.C.

Straw Hats: Manitoba price from 1911-12. British Columbia price from 1911-12.

Lining: No price St. Vincent de Paul or B.C.

Ticking: Kingston from 1911-12. No price for Dorchester. 
Barley: Alberta price from 1911-12.

Mutton: Dorchester price from 1911-12. Manitoba price from MD, Pay of Permanent Force Provisions and Supplies (PPFPS), Winnipeg. British Columbia price from PPFPS, Victoria and Equimalt (PPFPS VE).

Bacon/Pork: No pork prices. No bacon price for St.Vincent de Paul. Bacon price quotes for Dorchester from MD, Sussex Camp, PPFPS Fredericton, and IA, Indians of New Brunswick (INB). Manitoba prices from PPFPS Winnipeg.

Milk: No price for Dorchester or Manitoba.

Potatoes: Manitoba price from 1911-12.

Peas: British Columbia price quotes from PPFPS VE and IPR.

Prunes: No prices for St.Vincent de Paul or Manitoba. Dorchester prices from 1911-1912.

Currants and Raisins: No price for British Columbia.

Vinegar: Dorchester price from 1911-12.

Lard: Manitoba price from IA ES.

Molasses: No price for British Columbia or Alberta.

Tea: St. Vincent de Paul price from 1911-12.

Coffee: No price for Manitoba. St.Vincent de Paul price from MD, Three Rivers Camp and PPFPS, St. Jean, Quebec. British Columbia price from PPFPS VE.

Tobacco: No price for Dorchester or British Columbia.

Wood: Alberta price from PW, Edmonton Immigration Building. Dorchester prices from

MD, Sussex Camp and PPFPS Fredericton.

Japan Varnish: Not included.

Oils: No price for Dorchester.

$\underline{1913 / 1914}$

Braces: No price for Manitoba.

Denim: No price for St. Vincent de Paul or Manitoba.

Straw hats: Not included.

Linen: prices 1912-13 and 1913-14.

Ticking: No price for Manitoba or Saskatchewan.

Bacon/Pork: No pork prices used. No price for Saskatchewan. St.Vincent de Paul price from PPFPS St. Jean, Dorchester price from PPFPS Fredericton, and Manitoba prices from PPFPS Winnipeg.

Barley: Alberta price from 1912-13.

Beans: Kingston price from PPFPS, Kingston.

Tobacco: No price for Dorchester, Manitoba, British Columbia, or Saskatchewan.

Coffee: Manitoba price from PPFPS, Winnipeg.

Currants and Raisins: No price for British Columbia.

Lard: No price for Manitoba.

Molasses: No price for Saskatchewan.

Mutton: No price for Saskatchewan. Manitoba price from PPFPS, Winnipeg.

Potatoes: Manitoba price from PPFPS, Winnipeg.

Peas: No price for British Columbia.

Prunes: No price for St. Vincent de Paul or Manitoba.

Vinegar: Dorchester price from 1912-13.

Coal: No price for Alberta.

Coal oil: Saskatchewan price from 1912-13.

Wood: Kingston, KA and MD, $3^{\text {rd }}$ divisional area. 
Japan Varnish: No price for Dorchester or Alberta.

Turpentine: No price for Manitoba.

$\underline{1916 / 1917}$

Braces: No price for Manitoba, Alberta, or Saskatchewan.

Cotton: Alberta from IA Edmonton Agency. Saskatchewan from IA.

Denim: no price for Manitoba.

Straw hats: No price for Dorchester or Saskatchewan.

Linen: British Columbia price from naval dockyard, Esquimalt.

Lining: No price for St. Vincent de Paul or Dorchester.

Shirting: No price for Alberta.

Silesia: No price for B.C. or Saskatchewan.

Ticking: Only Kingston.

Bacon/Pork: No pork prices used. Kingston price from PPFPS Kingston. Montreal price

from PPFPS Quebec. Dorchester price from Royal Naval College (RNC) Halifax. Manitoba price from PPFPS Winnipeg. British Columbia price from PPFPS VE. Saskatchewan price from IA Assiniboine agency and various industrial schools.

Barley: No price for Dorchester, Manitoba, British Columbia, Alberta, or Saskatchewan. Tobacco: No price for Manitoba, Alberta, or Saskatchewan. Dorchester price from HMC dockyard Halifax, British Columbia price from HMC dockyard Esquimalt.

Coffee: No price for St. Vincent de Paul or Manitoba. Dorchester price from HMC dockyard Halifax.

Currants and Raisins: Dorchester price from HMC dockyard Halifax. British Columbia price from HMC dockyard Equimalt. Manitoba price from PPFPS Winnipeg.

Eggs: Dorchester price from RNC Halifax.

Fish: Manitoba price from PPFPS Winnipeg. Saskatchewan price from IA Assiniboine agency.

Lard: No price for Manitoba.

Milk: No price for Saskatchewan.

Molasses: No price for British Columbia or Saskatchewan.

Mutton: Kingston price from PPFPS Kingston. Dorchester price from RNC Halifax.

Manitoba price from PPFPS Winnipeg.

Pepper: No price for Manitoba or Alberta. Dorchester price from HMC dockyard Halifax.

Potatoes: Manitoba price from PPFPS Winnipeg. Alberta price from IA, Blood agency hospital.

Peas: No price for Alberta. British Columbia price from PPFPS VE.

Prunes: No price for St.Vincent de Paul or Manitoba.

Rice: Alberta price from IA, various agencies.

Tea: Saskatchewan price from IA, Assiniboine agency.

Vinegar: No price for Manitoba or Alberta. Dorchester price from HMC dockyard Halifax.

Soap: Manitoba price from IA ES. Alberta price from IA Blood agency, general expenses.

Coal: Alberta price from PPFPS Calgary.

Coal oil: Kingston price from MPWB Petawawa. St.Vincent de Paul price from MD,

Valcartier camp. Dorchester price from MD $6^{\text {th }}$ divisional area, Saint John. Manitoba price from PW, Minnedosa, public buildings. British Columbia price from PPFPS VE.

Saskatchewan price from IA, Assiniboine agency.

Wood: Kingston price from PPFPS Kingston. St.Vincent de Paul price from PPFPS Quebec. Dorchester price from PPFPS Halifax. British Columbia price from PPFPS VE. Alberta 
price from IA, various industrial schools.

Oils: Dorchester prices from ML, MD 6, and Halifax Dockyard. B.C. prices from MD 11 and prison.

Japan varnish: Dorchester price from ML. No price for Manitoba, Alberta, Saskatchewan. Turpentine: Dorchester price from ML. Manitoba price from MD 10.

\section{$\underline{1917 / 1918}$}

Braces: No price for St. Vincent de Paul.

Cotton: No price for British Columbia or Saskatchewan. Manitoba price from Invalided

Soldiers Commission (ISC), G unit.

Canvas: No price for Alberta.

Denim: No price for St. Vincent de Paul.

Straw Hats: No price for Dorchester, Manitoba, British Columbia, Alberta, or Saskatchewan.

Linen: No price for St. Vincent de Paul. Kingston price from KA, 1916-17 (year ending 31

Oct.).

Lining: Not included.

Serge: Kingston price from MD, Ottawa Headquarters. No price for B.C.

Shirting: No price for Manitoba.

Silesia: No price for Dorchester, Alberta, Saskatchewan.

Sole leather: No price for Alberta.

Ticking: Kingston and St. Vincent de Paul only.

Yarn: Alberta price, IA Stony Agency. Saskatchewan price, IA Assiniboine, Battleford and

Duck Lake Agencies.

Barley: No price for Dorchester, Manitoba, British Columbia, or Alberta.

Mutton: No price for Dorchester or British Columbia. Kingston price from KA, 1916-17.

Manitoba price from ISC, G Unit, Winnipeg. Saskatchewan price from MD, $12^{\text {th }}$ military district (MD 12).

Bacon/Pork: No prices for pork. No bacon prices for British Columbia. Kingston bacon price from MD, $3^{\text {rd }}$ military district, Kingston (MD 3). Dorchester bacon price from MD, $7^{\text {th }}$ military district, Saint John (MD 7). Manitoba bacon price from MD, $10^{\text {th }}$ military district, Winnipeg (MD 10).

Potatoes: Dorchester price from MD, Saint John. Manitoba price from PPFPS Winnipeg.

British Columbia price from MD, VE battery. Alberta price from MD, $13^{\text {th }}$ military district, Calgary (MD 13).

Peas: Manitoba price from MD 10. Alberta price from MD 13.

Prunes: Saint Vincent de Paul price from MD, $4^{\text {th }}$ military district, Montreal (MD 4).

Manitoba price from MD 10.

Currants or Raisins: No price for British Columbia. Dorchester price from MD 7. Manitoba price from MD 10.

Pepper: Manitoba price from MD 10. Alberta price from MD 13. Saskatchewan price from MD 12.

Vinegar: No price for Manitoba or Alberta.

Salt: St. Vincent de Paul price from MD 4.

Eggs: St. Vincent de Paul price from MD 4. Dorchester price from MD 7. British Columbia price from ISC, J unit, Esquimalt.

Lard: No price for Manitoba.

Molasses: No price for British Columbia or Saskatchewan.

Coffee: St. Vincent de Paul price from MD 4. Dorchester price from MD 7. Manitoba price 
from MD 10.

Tobacco: No price for Dorchester, Manitoba, British Columbia, or Saskatchewan.

Soap: Saskatchewan price from MD 12.

Coal: Alberta prices from MD 13 and ISC, I unit, Calgary.

Wood: No price from Dorchester or British Columbia. Kingston price from MD 3. Manitoba price from MD 10. Saskatchewan price from MD 12.

Coal Oil: Kingston price from MD 3. Dorchester price from MD 7. Manitoba price from MD 10. British Columbia price from MD, $11^{\text {th }}$ military district, Victoria (MD 11). Alberta price from MD 13. Saskatchewan price for "illuminating oil", from MD 12.

Cement: No price for Manitoba.

Lumber: Manitoba price from MD 10 and Brandon experimental farm.

Oils: NWMP Regina and PW Rosthern Experimental Farm for Saskatchewan prices.

Manitoba price from MD 10.

Japan Varnish: Not included.

Turpentine: Alberta price from MD 13. RNWMP Regina price for Saskatchewan.

\section{$\underline{1918 / 1919}$}

Braces: Kingston only. Prices from KA and suspenders bought by Kingston Pen.

Canvas: No price for British Columbia or Saskatchewan.

Cotton: Kingston prices from KA and Kingston Penitentiary. No price for British Columbia. St. Vincent de Paul price from ML, Quebec. Dorchester price from ML, PEI. Alberta price from IA, various agencies. Saskatchewan price from IA, various agencies.

Denim: No price for Dorchester or B.C.

Straw hats: Not included.

Linen: Not included.

Lining: Kingston price from KA. No price from St. Vincent de Paul or Saskatchewan.

Serge: No price from Manitoba.

Silesia: Kingston price from KA. Only other price from St. Vincent de Paul.

Sole leather: Kingston price from KA and Kingston Penitentiary.

Ticking: Not included.

Tweed: No price for British Columbia or Saskatchewan.

Yarn: No price for B.C.

Bacon/Pork: No price for St. Vincent de Paul or Dorchester. Kingston price from RMC mess. Manitoba price from IA Birtle. British Columbia price from PPFPS VE. Alberta price from IA, Edmonton agencies. Saskatchewan price from IA, various agencies.

Barley: No price from St. Vincent de Paul, Dorchester, or British Columbia. Manitoba price from IA, Birtle and Portage la Prairie agencies. Alberta price from IA Edmonton agency.

Saskatchewan price from IA, various agencies.

Beans: Not included.

Tobacco: No price for Dorchester, Manitoba, British Columbia, or Saskatchewan.

Coffee: No price from Manitoba. St.Vincent de Paul from ML, Quebec. Dorchester price from ML, Nova Scotia.

Currants and raisins: No price for St.Vincent de Paul, Manitoba, or Alberta. Dorchester price from ML, Nova Scotia. British Columbia price from PPFPS VE.

Eggs: No price for Manitoba or Saskatchewan. St.Vincent de Paul price from ML, Quebec.

Dorchester price from ML, Nova Scotia. British Columbia price from PPFPS VE.

Fish: Manitoba price from PPFPS, Winnipeg.

Lard: No price for Manitoba or Alberta. Saskatchewan price from IA Assiniboine agency. 
Molasses: No price for British Columbia, Alberta, or Saskatchewan.

Mutton: No price for St.Vincent de Paul, Dorchester, Manitoba, Alberta, or Saskatchewan. Kingston price from RMC mess. British Columbia price from RNC Victoria.

Pepper: No price for Dorchester, Manitoba, Alberta, or Saskatchewan. British Columbia price from PPFPS VE.

Potatoes: No price for Saskatchewan. Dorchester price from ML Nova Scotia. Manitoba price from PPFPS Winnipeg. Alberta price from IA Lesser Slave Lake agency.

Peas: Not included.

Prunes: No price for St.Vincent de Paul or Manitoba.

Salt: No price for Manitoba, Alberta, or Saskatchewan.

Tea: Manitoba price from IA, Pas and Portage la Prairie agencies. Alberta price from IA

Edmonton agency.

Vinegar: No price for Dorchester, Manitoba, British Columbia, Alberta, or Saskatchewan.

Soap: No price for Dorchester. Manitoba price from IA, Lake la Crosse agency.

Saskatchewan price from IA, various Saskatchewan agencies.

Coal oil: No price from British Columbia. Kingston price from MD 3. Dorchester price

from ML, Nova Scotia. Manitoba price from IA, Birtle agency. Alberta price from IA,

Blood agency hospital. Saskatchewan price from IA, Assiniboine agency.

Wood: Kingston price from MPWB Peterborough, Renfrew, and Pembroke. Dorchester price from PPFPS Halifax. British Columbia price from PPFPS VE and IA, various agencies.

Alberta price from IA Edmonton agency. Saskatchewan price from IA Duck Lake agency. Iron: Manitoba price from MD 10. B.C. price from MD 11. Saskatchewan price from

RNWMP Regina and MD 12.

Nails: ML price for Dorchester. No price for Manitoba. B.C. price from MD 11.

Oils: Dorchester price from MD 6.

Japan Varnish: not included.

Turpentine: ML for Dorchester prices. MD 11 and ML for B.C. MD 12 and RNWMP Regina for Saskatchewan. No price for Manitoba.

\section{$\underline{1919 / 1920}$}

Braces: Kingston price from KA.

Canvas: No price for British Columbia.

Cotton: British Columbia price from MD 11. Saskatchewan price from MD 12.

Denim: No price for B.C.

Straw Hats: Not included.

Linen: No price for St.Vincent de Paul, Dorchester, Manitoba, Alberta, or Saskatchewan.

Serge: British Columbia price from HMC Dockyard Esquimault.

Shirting: No price for Alberta or Saskatchewan

Silesia: Kingston only.

Ticking: Kingston and St. Vincent de Paul only.

Tweed: No price for Saskatchewan.

Bacon/Pork: No pork prices used. Kingston price from RMC, Kingston. St.Vincent de Paul price from MD 4. Dorchester price from PPFPS Halifax. Manitoba price from MD 10. British Columbia price from PPFPS VE. Alberta price from MD 13. Saskatchewan price from MD 12.

Barley: No price for Alberta. B.C. price from HMC dockyard, Esquimalt.

Tobacco: Not included.

Coffee: Not included. 
Currants and Raisins: Dorchester price from HMC dockyard Halifax. Manitoba price from MD 10. British Columbia price from MD 11.

Eggs: St.Vincent de Paul price from MD 4. Dorchester price from PPFPS Halifax. Manitoba price from MD 10. British Columbia price from PPFPS VE. Saskatchewan price from MD 12.

Fish: St.Vincent de Paul price from MD 4.

Lard: No price from Manitoba or Alberta.

Molasses: Not included.

Mutton: No price for Manitoba. Dorchester price from PPFPS Halifax. British Columbia price from MD 11. Alberta price from MD 13. Saskatchewan price from MD 12.

Pepper: No price for Dorchester, Manitoba, British Columbia, Alberta, or Saskatchewan. Potatoes: St.Vincent de Paul price from MD 4. Dorchester price from PPFPS Halifax.

Manitoba price from MD 10. British Columbia price from PPFPS VE. Alberta price from MD 13. Saskatchewan price from MD 12.

Peas: No price from British Columbia or Alberta.

Prunes: St.Vincent de Paul price from MD 4. Manitoba price from MD 10. Alberta price from MD 13.

Salt: British Columbia price from HMC dockyard Esquimalt.

Tea: Kingston price from MD 3. St.Vincent de Paul from MD 4.

Vinegar: No price for British Columbia, Alberta, or Saskatchewan. Dorchester price from Amherst Alien Internment Camp (run by Department of Justice). Manitoba price from MD 10.

Soap: Saskatchewan price from IA, various Saskatchewan agencies.

Coal: Dorchester price from PPFPS Halifax. Alberta price from PPFPS Calgary.

Coal oil: No price from St. Vincent de Paul or British Columbia. Kingston price from IA, 6 nations and Wildland trust. Dorchester price for ML, PEI and Nova Scotia. Manitoba price from MD 10. Alberta price from MD 13. Saskatchewan price from RCMP Saskatchewan and RCMP South Saskatchewan "A"

Wood: Kingston price from RMC Kingston. Dorchester price from MD 7. British Columbia price from MD 11. Alberta price from RCMP Edmonton G division. Saskatchewan price from MD 12.

Nails: ML for B.C. price.

Oils: MD 10 for Manitoba price. ML and prison for B.C. prices. MD 13 and prison for

Alberta prices. RNWMP Regina and prison for Saskatchewan prices.

Japan Varnish: Not included.

Turpentine: No price for Manitoba or Alberta. Saskatchewan price from RNWMP Regina.

$\underline{1920 / 1921}$

Braces: No price for St.Vincent de Paul, Manitoba, British Columbia, Alberta, or

Saskatchewan.

Canvas: No price for Alberta.

Cotton: Alberta price from IA, various Alberta agencies. Saskatchewan price from IA, various Saskatchewan agencies.

Denim: No price for Dorchester, B.C., or Alberta.

Straw Hats: Kingston only.

Linen: Kingston and Manitoba only.

Lining: No price for Alberta.

Serge: No price for Alberta. 
Shirting: No price for St. Vincent de Paul, B.C. or Alberta.

Silesia: No price for Alberta or Saskatchewan.

Sole Leather: No price for Alberta.

Ticking: Not included.

Tweed: No price for Alberta.

Yarn: No price for Alberta

Bacon/Pork: No pork prices used. Kingston price from PPFPS Kingston. St.Vincent de Paul price from PPFPS Montreal. Dorchester price from PPFPS Halifax. Manitoba price from PPFPS Winnipeg. British Columbia price from PPFPS VE. Alberta price from PPFPS Calgary. Saskatchewan price from IA, Duck Lake agency.

Tobacco: No price for Dorchester, Manitoba, British Columbia, or Saskatchewan.

Coffee: St.Vincent de Paul price from PPFPS Montreal. Dorchester price from ML, PEI. Manitoba price from PPFPS Winnipeg.

Currants and Raisins: Manitoba price from PPFPS Winnipeg. British Columbia price from PPFPS VE. Alberta price from PPFPS Calgary.

Eggs: No price for Saskatchewan. Dorchester price from PPFPS Halifax. British Columbia price from PPFPS VE.

Fish: St.Vincent de Paul price from PPFPS Montreal. British Columbia price from PPFPS VE.

Flour: Alberta price from PPFPS Calgary.

Lard: No price for Saskatchewan. Manitoba price from demobilization appropriation, Winnipeg.

Molasses: No price for British Columbia, Alberta, or Saskatchewan.

Mutton: Dorchester price from HMCS "WH Lee", HMC submarines, Halifax. Manitoba price from PPFPS Winnipeg. British Columbia price from PPFPS Winnipeg. Alberta price from PPFPS Calgary.

Pepper: No price for Alberta or Saskatchewan. Kingston price from demobilization appropriation, Toronto. Dorchester price from PPFPS Halifax. Manitoba price from PPFPS Winnipeg. British Columbia price from PPFPS VE.

Potatoes: No price for Saskatchewan. Dorchester price from PPFPS Halifax. Manitoba price from PPFPS Winnipeg. British Columbia price from PPFPS VE. Alberta price from PPFPS Calgary.

Peas: No price for Alberta. British Columbia price from PPFPS VE.

Prunes: Alberta price from PPFPS, Calgary.

Rice: Alberta price from IA, various agencies.

Salt: No price for Alberta. British Columbia price from Esquimalt dockyards.

Tea: Alberta price from PPFPS Calgary.

Vinegar: No price for Manitoba, Alberta, or Saskatchewan. Dorchester price from ML, Nova

Scotia. British Columbia price from Esquimalt dockyards.

Soap: No price for Manitoba. Alberta price from IA, various agencies.

Coal: Alberta price from IA, various agencies.

Coal oil: No price for Dorchester. Kingston price from MPWB Petawawa. Manitoba price from Demobilization allocation, Winnipeg. British Columbia price from Esquimalt

dockyards. Edmonton price from IA, various agencies. Saskatchewan price from IA, various agencies.

Wood: No price for Dorchester. Kingston price from MPWB Picton. British Columbia price from IA, various agencies. Alberta price from IA, various agencies. Saskatchewan price from MPWB Saskatoon and IA, various agencies.

Cement: MD 13 for Alberta price. 
Iron: MD 11 for B.C. price.

Nails: ML for Dorchester price. No price for B.C. or Alberta.

Oils: ML for B.C. price. PW Lethbridge experimental farm for Alberta price. MD 12 and prison for Saskatechewan.

Japan Varnish: No price for Manitoba, B.C., Alberta, or Saskatchewan.

Turpentine: Edmonton RNWMP and Lethbridge Experimental Farm for Alberta prices.

\section{$\underline{1921 / 1922}$}

Braces: Not included.

Cotton: Saskatchewan price from IA, File Hills and Moose Mountain agencies.

Straw hats: Kingston only.

Linen: Not included.

Silesia: No price for Saskatchewan.

Ticking: No price for Manitoba, British Columbia or Saskatchewan.

Tweed: Kingston only.

Sole leather: Not included.

Bacon/Pork: No pork prices used. Kingston price from PPFPS Kingston. St.Vincent de Paul price from PPFPS Montreal. Dorchester price from PPFPS Halifax. Manitoba price from PPFPS Winnipeg. British Columbia price from PPFPS VE. Saskatchewan price from MD 12 (annual drill).

Barley: Not included.

Coffee: Kingston price from PPFPS Toronto. Dorchester price from PPFPS Halifax.

Manitoba price from PPFPS Halifax.

Currants and raisins: British Columbia price from PPFPS VE.

Eggs: No price for Saskatchewan. Dorchester price from PPFPS Halifax.

Lard: No price for Saskatchewan. Manitoba price from PPFPS Winnipeg.

Milk: Dorchester price from PPFPS Halifax.

Mutton: No price for Saskatchewan. Dorchester price from HMC submarines, Halifax.

Manitoba price from PPFPS Winnipeg.

Pepper: Kingston price from PPFPS Toronto. Dorchester price from PPFPS Halifax. British Columbia price from PPFPS VE.

Potatoes: Manitoba price from PPFPS Winnipeg. British Columbia price from PPFPS VE.

Saskatchewan price from MD 12.

Peas: No price for British Columbia.

Vinegar: No price for Manitoba, British Columbia, or Saskatchewan.

Coal oil: Kingston price from PW, dredging, Ottawa River. Dorchester price from MF, Margaree NB fish hatchery. Manitoba price from IA, Pas agency. Saskatchewan price from IA, various agencies. No price for B.C.

Wood: Kingston price from MPWB Cornwall. Dorchester price from MD 6 and 7 (annual drill). British Columbia price from MPWB Kelso. Saskatchewan price from MD 12 (annual drill) and IA, various agencies.

Oils: MD 10 for Manitoba price. Esquimalt Dockyard for B.C. price. PW Experimental Farm Indian Head, and IA File Hills Agency for Saskatchewan. (also prison prices for all three penitentiaries.)

Japan Varnish: No price Manitoba, B.C. or Saskatchewan. 
Braces: No price for Manitoba, British Columbia, or Saskatchewan.

Canvas: No price for Manitoba.

Cotton: No price for Manitoba, B.C. or Saskatchewan

Straw Hats: Kingston only.

Linen: Not included.

Serge: Not included.

Ticking: No price for Manitoba or British Columbia.

Tweed: Not included.

Yarn: No price for Manitoba. Saskatchewan from IA, several agencies.

Barley: Not included.

Rice: No price for Dorchester. St.Vincent de Paul price from PPFPS Montreal. Manitoba

price from PPFPS Manitoba. Saskatchewan price from IA, Battleford Agency.

Fish: No price for Saskatchewan.

Mutton: No price for Dorchester or Saskatchewan. Manitoba price from PPFPS Winnipeg. Bacon/Pork: No pork prices used. Kingston bacon price from PPFPS Kingston. Manitoba bacon price from PPFPS Winnipeg. British Columbia price from PPFPS VE. Saskatchewan price from IA, Battleford agency.

Milk: Dorchester prices from PPFPS Halifax, Soldiers' Civil Re-establishment (SCR), Unit B, Halifax, and SCR Unit K, Fredericton. Manitoba price from PPFPS Winnipeg and SCR, Unit G, Winnipeg.

Potatoes: Manitoba price from PPFPS Winnipeg.

Peas: No price for Saskatchewan.

Prunes: No price for Manitoba. British Columbia price from PPFPS VE.

Currants and Raisins: British Columbia prices from PPFPS VE.

Vinegar: No price for Manitoba, British Columbia, or Saskatchewan.

Pepper: Not included.

Eggs: No price for Dorchester. British Columbia price from 1923-24.

Lard: No price for Manitoba or Saskatchewan.

Molasses: No price for Manitoba, British Columbia, or Saskatchewan.

Coffee: Dorchester prices from MD 7 and from SCR, Unit K, Fredericton. Manitoba price from PPFPS Winnipeg.

Tea: Kingston price for SCR, Unit C, Kingston.

Coal Oil: St. Vincent de Paul and Kingston prices from PW, dredging. Saskatchewan price from RCMP Prince Albert. B.C. price from RCMP Midway and Stewart. no price for Dorchester or Manitoba.

Soap: St. Vincent de Paul price from SCR, Unit A, Montreal.

Wood: Kingston price from PPFPS Kingston. Dorchester price from MD 7. British

Columbia price from RCMP Vancouver. Saskatchewan prices from IA, Battleford agency and RCMP Humboldt.

Oils: MD 10 for Manitoba, and prison prices.

Japan Varnish: Not included. 